\title{
Between Philology and Friendship: Dante and Aquinas Revisited
}

\author{
"Dio vede tutto, e tuo veder s'inluia", \\ diss' io, "beato spirto, sì che nulla \\ voglia di sé a te puot' esser fuia. \\ Dunque la voce tua, che 'l ciel trastulla \\ sempre col canto di quei fuochi pii \\ che di sei ali facen la coculla, \\ perché non satisface a' miei disii? \\ Già non attendere' io tua dimanda, \\ s'io m'intuassi, come tu t"inmii".
}

$($ Par. IX.73-81)

1. Preliminary considerations: Dante, Aquinas and intimations of otherness. 2. Patterns of deconstruction and reconstruction: Nardi, Gilson and Foster. 3. An alternative proposal: modes of reading and reception. 4. Dante and the theological project: theology and the crisis of existence. 5. Conclusion: philology, friendship and the common proclamation.

Perhaps the single most important accomplishment of twentieth-century Dante scholarship - certainly in the area of philosophy and theology was the separating out of Dantean and Thomist spirituality, a process which, though coloured by the properties of personality, culminated by virtue of the energy and erudition of those party to it in a fresh sense both of what Dante owed to Thomas as more than ordinarily accomplished in the ways of Christian-theological intelligence and of what made of him his own man, a Christian thinker quite other in kind than Aquinas. Approaches to the issue were as many and varied as those who cared to address it, but for the moment we may settle for just three, the first two to an extent mutually dependent, the third presupposing them both, but each

\footnotetext{
1 "God sees all, and into him your vision sinks, blessed spirit", I said, "so that no wish may steal itself from you. Why then does your voice, which ever gladdens heaven together with the singing of those devout fires that make themselves a cowl with the six wings - not satisfy my longings? Surely I should not wait for your request were I in you even as you are in me."
} 
committed to the business of disentanglement, of marking the difference between one species of Christian spirituality and another. First, then, there was Bruno Nardi with his at times abrasive sense, not only of the otherness of Dantean and Thomist positions in the areas of cosmology and metaphysics, but of the often more Albertan than Thomist complexion of Dante's thinking in these and related areas of concern. Then there was Etienne Gilson, who, while himself an occasionally militant spirit, was notable above all for his patient account of what he saw as, vis-à-vis that of Thomas, the more differentiated character of Dantean teleology, its tendency towards a more phased or periodic account of human experience in its positive unfolding. And finally there was Kenelm Foster, who, as one authorized by profession to pronounce in this matter, made it his business, not only to confirm Dante's admiration and indeed love for Thomas in the twofold piety and precision of his mind, but to stress as a matter both of temperamental and of methodological difference the depth of their divergence in the areas particularly of anthropology, epistemology and creation theology. Well before the end of the century, then, the myth of Dante's Thomism, at least in its more indiscriminate reaches, had as a result of these and of similar interventions been put to rest and the way opened up for a more responsible account of Dante's relationship with one of the most cherished of his auctores. ${ }^{2}$

${ }^{2}$ P. H. Wicksteed, Dante and Aquinas (London: Dent and New York: Dutton, 1913, with a facsimile reprint Honolulu (Hawaii): University Press of the Pacific, 2002); G. Busnelli, Cosmogonia e antropogenesi secondo Dante Alighierie le sue fonti (Rome: Civiltà cattolica, 1922, with a review by Nardi in the Giornale storico della letteratura italiana 81 (1923), 307-34 and reproduced in his Saggi di filosofia dantesca (note 3 below), pp. 341-80); V. Vettori, 'S. Tommaso e Dante oggi', in Tommaso d’Aquino nella storia del pensiero (Naples: Edizioni Domenicane Italiane, 1976), vol. 2 (Dal medioevo ad oggi), pp. 149-51; M. Corti, Dante a un nuovo crocevia (Florence: Sansoni, 1982); eadem, La felicità mentale: nuove prospettive per Cavalcanti e Dante (Turin: Einaudi, 1983); E. Stump, 'Dante's Hell, Aquinas' Moral Theory, and the Love of God', Canadian Journal of Philosophy 16 (1986), 2, 181-98; B. Panvini, 'La concezione tomistica della grazia nella Divina Commedia', in Letture classensi 17 (Ravenna: Longo, 1988), pp. 69-85; L. M. La Favia, 'Thomas Aquinas and Siger of Brabant in Dante's Paradiso', in Lectura Dantis Newberryana II (Chicago, Illinois, 19851987), ed. P. Cherchi and A. C. Mastrobuono (Evanston, Ill.: Northwestern University Press, 1990), pp. 147-72; A. C. Mastrobuono, Dante's Journey of Sanctification (Washington DC: Gateway, 1990); R. D. Crouse, 'Dante as Philosopher. Christian Aristotelianism', Dionysius 16 (1998), 141-56; M. Cogan, The Design in the Wax. The Structure of the Divine Comedy and its Meaning (Notre Dame and London: University of Notre Dame Press, 1999); A. A. Iannucci, 'Dante's Theological Canon in the Commedia', Italian Quarterly 37 (2000), 51-56; idem, 'Tommaso e il canone teologico in Dante', in La Ciociaria tra letteratura e cinema. Atti del Convegno di Studi, Ripi 17-20 gennaio 2002, ed. F. Zangrilli (Pesaro: Metauro, 2002), pp. 317-26; A. Gagliardi, 'Dante fra Sigieri e Tommaso', in Tommaso J'Aquino e Averroè. La visione di Dio (Soveria Mannelli: Rubbettino, 2002), pp. 273-94; W. Metz, 'Das Weltgericht bei Dante in Differenz zu Thomas von Aquin', in 
2. Bruno Nardi's critique of the Thomist gloss on Dante rests upon an incomparable familiarity with medieval philosophy in its central emphases and endless by-ways. ${ }^{3}$ Committed as he was to an interpretation of the text in terms of the variety of its sources and allegiances in the areas both of

Ende und Vollendung. Eschatologische Perspektiven im Mittelalter, ed. J. A. Aertsen and M. Pickavé (Berlin and New York: Gruyter, 2002), pp. 626-37; G. Mazzotta, 'The Heaven of the Sun: Dante between Aquinas and Bonaventure', in Dante for the New Millennium, ed. T. Barolini and H. W. Storey (New York: Fordham University Press, 2003), pp. 152-68; F. Adorno, 'Dante (1265-1321), tra San Tommaso (1225/26-1274) e San Bonaventura (1221-1274)', in Filosofi J'oggi per Dante, ed. N. Ancarani, Letture classensi 32-34 (Ravenna: Longo, 2005), pp. 13-22.

${ }^{3}$ On Nardi as a dantista, T. Gregory, 'Bruno Nardi', Giornale critico della filosofia italiana 22 (1968), 469-501 (also, with G. Petrocchi, 'Ricordo di Bruno Nardi', in L'Aligbieri. Rassegna bibliografica dantesca 20 (1979), 1, 3-16, and, with P. Mazzantini (eds), Gli scritti di Bruno Nardi', in 'Lecturae' ed altri studidanteschi (Florence: Le Lettere, 1990), pp. 285 312); E. Garin, 'Ricordo di Bruno Nardi (1884-1968)', Studidanteschi 45 (1969), 5-28; C. Vasoli, 'Bruno Nardi dantista', in Letteratura italiana: I critici, vol. 3 (Milan: Marzorati, 1970), pp. 2023-51; idem, 'Bruno Nardi e il "restauro” della filosofia di Dante', Letteratura e filologia tra Svizzera e Italia. Studi in onore di Guglielmo Gorni, 3 vols, ed. M. A. Terzoli et al. (Rome: Edizioni di Storia e Letteratura, 2010), vol. 1 (Dante: la Commedia e altro), pp. 57-73; A. Schiaffini, 'Bruno Nardi filologo e scrittore', in Italiano antico e moderno, ed. T. De Mauro and P. Mazzantini (Milan and Naples: Ricciardi, 1975), pp. 331-39; A. Vallone, Storia della critica dantesca dal XIV al XX secolo, 2 vols (Milan: Vallardi, 1981), vol. 2, pp. 890-93; idem, 'Bruno Nardi "lettore” di Dante con Appendice di lettere inedite', in Profilie problemidel dantiomo (Naples: Liguori, 1985), pp. 355-420; F. Mazzoni, 'Bruno Nardi dantista', in L'Alighieri. Rassegna bibliografica dantesca 23 (1982), 2, 8-28; T. Nardi, 'Dal carteggio di Bruno Nardi', in La Società Dantesca Italiana 1888-1988 (Atti del Convegno Internazionale, Firenze 24-26 novembre 1988, ed. R. Abardo (Milan and Naples: Ricciardi, 1995), pp. 89-97; G. M. Cao, 'Appunti storiografici in margine al carteggio Gilson-Nardi', in Giornale critico della filosofia italiana, 6th series, 21 (2001), 137-70; O. Capitani, 'Bruno Nardi e il percorso dantesco dal Convivio alla Commedia', in Medievistica e medievisti nel secondo Novecento (Spoleto: Centro Italiano di Studi sull'Alto Medioevo, 2003), pp. 23962 (originally the introduction to the second edn of Dal Convivio alla Commedia (Rome: Istituto Italiano per il Medio Evo, 1992), pp. 5-29). Nardi himself on Dante and Thomas, 'Intorno al tomismo di Dante e alla quistione di Sigieri', Giornale Dantesco 22 (1914), 182 97; 'Il tomismo di Dante e il P. Busnelli S.J.', Giornale storico della letteratura italiana 81 (1923), 307-34 (a review of G. Busnelli, Cosmogonia e antropogenesi secondo Dante Alighieri e le sue fonti (note 2 above), also in Saggi difilosofia dantesca, 2nd edn (Florence: La Nuova Italia, 1967), pp. 341-80); Dante e la cultura medievale (Bari: Laterza, 1942, in a new edn by P. Mazzantini with an introduction by T. Gregory (Rome and Bari: Laterza, 1983)); review of F. Orestano, 'Dante e "il buon frate Tommaso"' (Sophia 9 (1941), 1-19), Studi danteschi 26 (1942), 148-60; Nel mondo di Dante (Rome: Edizioni di Storia e Letteratura, 1944); Dal 'Convivio' alla 'Commedia': sei saggi danteschi (Rome: Nella sede dell'Istituto, 1960; in a new edn with a preface by O. Capitani (Rome: Istituto Storico Italiano per il Medio Evo, 1992)); Saggie note di critica dantesca (Milan: Ricciardi, 1966); 'Lecturae' e altri studi danteschi, ed. R. Abardo (Florence: Le Lettere, 1990). For a general bibliography, Saggi sulla cultura veneta del Quattro e Cinquecento, ed. P. Mazzantini (Padua: Antenore, 1971), pp. ix-xlix. 
philosophy and of theology, he was never less than impatient (a) with too ready a referral of Dante to Aquinas as in any sense paramount among his authorities, (b) with instances of intertextuality reducible to the mere голло of scholastic discourse, and (c) with the least hint of carelessness in respect of the precise form of the source text, be it Thomist or otherwise, and thus as regards its precise meaning. Exemplary in respect of the first of these is the following passage on Busnelli's alignment of Thomas and Dante in the field of general cosmology, this, Nardi thinks, being but another instance of his at-all-costs attempt, if not to reconcile the unreconcilable exactly, then to extract from the text a meaning other than that evidently intended by the author: "il passo della stessa opera [Contra gentiles], II.30, tende a dimostrare che le cose create possono dirsi assolutamente necessarie per rapporto ai principii prossimi di cui risultano. Così, per il fatto che gli esseri del mondo inferiore son costituiti di materia e di forma, e siccome la loro materia è in potenza a ricevere forme contrarie, essi sono necessariamente corruttibili. Al contrario, poiché la forma è atto e non potenza, quando essa sussiste senza materia, come nelle intelligenze separate, oppure esaurisce tutta la potenza della materia, com'è il caso dei corpi celesti, è necessariamente incorruttibile. Io chiedo al Busnelli che cosa ha che fare questo discorso col passo in cui Dante afferma, con alcuni vecchi Dottori scolastici, che "Dio in principio creò tre cose": la pura forma (le intelligenze), la materia informe (soggetto dei quattro elementi) e il composto indissolubile di materia e di forma (i cieli)!’4 In fact, the issue may be more delicate than Nardi supposed, for

${ }^{4}$ The passage drawn from the same work ( $S c G$ II.xxx) sets out to show how things which are created might be said to be absolutely necessary as regards the proximate principles from which they flow. So, by virtue of the fact that beings here below are made up of form and matter, and that their matter is in potential to receiving other forms, they are necessarily corruptible. Since form, by contrast, is act rather than potency, whenever it subsists immaterially (as in the separate substances), or when it exhausts the whole potentiality of matter (as with the heavenly bodies), it is necessarily incorruptible. I therefore ask of Busnelli what all this has to do with the passage in which, with some of the old scholastic doctors, Dante affirms that "God in the beginning created three things", pure form (the Intelligences), uninformed matter (the subject of the four elements), and the indissoluble amalgamation of matter and form (the heavens)! (Saggidifilosofia dantesca (note 3 above), p. 343). For the triple procession of pure form, pure matter and their amalgamation in the superlunary world from the Godhead, Par. XXIX.10-36. Thomas, in the passage indicated ( $S c G$ II.xxx.9-11), has 'Ex his autem principiis, secundum quod sunt essendi principia, tripliciter sumitur necessitas absoluta in rebus. Uno quidem modo, per ordinem ad esse eius cuius sunt. Et quia materia, secundum id quod est, ens in potentia est; quod autem potest esse, potest etiam et non esse: ex ordine materiae necessario res aliquae corruptibiles existunt; sicut animal quia ex contrariis compositum est, et ignis quia eius materia est contrariorum susceptiva. Forma autem, secundum id quod est, actus est: et per eam res actu existunt. Unde ex ipsa provenit necessitas ad esse in quibusdam. 
as often as not when it comes to Dante and his auctores it is a question, not so much of the what, as of the bow of his reading, of what, over and beyond (or even over and against) the author's original intention, he chooses to find there - at which point reading shades off into reception as the nub of the issue. For Nardi, however, this is not the point, for at the level of authorial intention they are simply not talking about the same thing. And that is not all, for even when they are talking about the same thing, it often comes down, Nardi thinks, to the mere commonplaces of the scholastic mind, these, therefore, as a means of identifying patterns of allegiance and of antagonism, making for something less than good scholarship; so, for example, on Dante's supposed recourse to the Contra gentiles in the areas of creation theology and of astral determinism, these remarks, peremptory as ever, on the unexceptionality of it all: 'il passo della stessa somma Contra gent., II.19, e gli altri affini, in cui è detto che la creazione è passaggio istantaneo dal non essere all'essere, simile al diffondersi della luce, secondo la fisica antica, racchiude un concetto comune fra gli Scolastici ... la citazione di San Tommaso, ov'è detto che i cieli influiscono colla luce e col moto, è superflua. Si tratta di un luogo comune. ${ }^{5}$ Here,

Quod contingit vel quia res illae sunt formae non in materia: et sic non inest ei potentia ad non esse, sed per suam formam semper sunt in virtute essendi; sicut est in substantiis separatis. Vel quia formae earum sua perfectione adaequant totam potentiam materiae, ut sic non remaneat potentia ad aliam formam, nec per consequens ad non esse: sicut est in corporibus caelestibus. In quibus vero forma non complet totam potentiam materiae, remanet adhuc in materia potentia ad aliam formam. Et ideo non est in eis necessitas essendi, sed virtus essendi consequitur in eis victoriam formae super materia: ut patet in elementis et elementatis. Forma enim elementi non attingit materiam secundum totum eius posse: non enim fit susceptiva formae elementi unius nisi per hoc quod subiicitur alteri parti contrarietatis. Forma vero mixti attingit materiam secundum quod disponitur per determinatum modum mixtionis. Idem autem subiectum oportet esse contrariorum et mediorum omnium, quae sunt ex commixtione extremorum. Unde manifestum est quod omnia quae vel contrarium habent vel ex contrariis sunt, corruptibilia sunt. Quae autem huiusmodi non sunt, sempiterna sunt: nisi per accidens corrumpantur, sicut formae quae non subsistunt sed esse earum est per hoc quod insunt materiae.'

${ }^{5}$ the passage from the selfsame Summa contra gentiles (II.19), and others like it, where - somewhat after the manner of the diffusion of light in ancient physics - it is said that creation is a matter of the immediate passage from non-being to being, embodies a notion common among the scholastics ... the quotation from Saint Thomas, where it is said that the heavens exercise their influence by their light and their movement, is superfluous, for this is a mere commonplace (Saggi di filosofia dantesca (note 3 above), pp. 343 and 353). Spirited in this respect, p. 354: 'Il ravvicinare, quindi, questa dottrina antica alle dottrine dei moderni astronomi, sull'azione che certi corpi celesti esercitano sulla terra, è una specie di concordismo molto simile a quello biblico dell'abate Moigno; meglio ancora, una tardiva e inaspettata difesa dei dilemmi di Don Ferrante.' Thomas, at II.xix.6, has 'Relinquitur igitur quod creatio sit in instanti. Unde simul aliquid, dum creatur, creatum est: sicut simul illuminatur et illuminatum est.' 
then, it is a question of discernment, of the kind of sixth sense whereby those genuinely expert in these things pick up on the significant instance. And finally, there is Nardi's impatience at the philological level, where anything less than scrupulous attention to editorial exactness spells disaster for exact understanding. Exemplary in this sense is the following passage on the difference between seminal reason as a property of matter and the virtual presence of the idea to the Creator as its author and origin, where Busnelli, addressing a passage in the Dantean Quaestio but misled as to punctuation, is said by Nardi to confuse the issue:

per dimostrarmi che Dante nega nella materia le rationes seminales, il Busnelli mi cita questo passo della Quaestio, XVIII, 46:

Cum omnes forme, que sunt in potentia materie idealiter, sint in actu in Motore celi ...

A p. 16, n. 1, il Busnelli aveva dichiarato di riferirsi, per le citazioni di Dante, al testo critico della Società Dantesca. Ora invece, zitto zitto, senza darne avviso al lettore, mi trasporta, come fanno altre edizioni, la virgola che nel testo critico è, con ragione, dopo la parola materie, e non dopo idealiter, e così mi cambia tutto il senso del passo citato. È vero che il Busnelli potrebbe farsi forte di altre edizioni. Ma egli avrebbe torto. Prima di tutto, perché il passo della Quaestio va messo in relazione coi versi 127-138 del canto II e coi versi 67-69 del canto XIII del Paradiso. Poi per un'altra ragione: il passo d'Averroè, citato da Dante, non si trova nel De substantia orbis, ma nel commento alla Metafisica, e suona così:

Omnes proportiones et formae sunt in potentia in prima materia et in actu in primo Motore.

L'idealiter non c'è; ma Dante, che cita a senso, senza avere il testo sotto gli occhi, l'ha aggiunto per render meglio il significato. Anche Tommaso cita questo passo, nel II delle Sentenze, per provare l'esistenza delle $i d e e$ in Dio. ${ }^{6}$

${ }^{6}$ for the purposes of convincing me how it is that Dante denies the presence in matter of seminal reasons, Busnelli cites the passage from the Quaestio at XVIII, 46: "Since all forms, which are ideally present in matter potentially, are in act in the mover of the heavens .... On p. 16 at note 1, Busnelli had made it plain that, when it comes to quoting Dante, he had used the critical text of the Società Dantesca. Now, however, without so much as a word, he follows other editions in relocating the comma which, in the critical text, and with good reason, is put, not after 'idealiter', but after 'materie', thus changing the entire sense of the quotation. True, Busnelli could well draw comfort in this from the other editions, but he would be wrong in doing so, above all because the passage from the Quaestio needs to be set alongside lines 127-38 of Canto II of the Paradiso and 
Unmistakable here is the note of philosophical and philological triumphalism never far beneath the surface in Nardi as one exceptionally competent in the field; but never even so is there any attempt in his work to minimize, still less to spirit away, Thomas's presence to Dante as to the fore among his auctores, as tending to shape the notional or expressive instance. On the contrary, he has by his own admission no axe to grind, no 'mulino antitomistico' where Dante is concerned, ${ }^{7}$ for, Thomas, certainly, is there, if as but one of those from whom Dante derived comfort in respect of this or that inflexion of the spirit: 'Né tomista, né antitomista, Dante prende il materiale della sua informazione filosofica con largo spirito eclettico, nel ricco arsenale della Scolastica, senza esclusione di scuole; e quel materiale poi rifonde nel crogiuolo della sua mente, collo sforzo della riflessione personale, in quell'ardente crogiuolo da cui escono, temprati di pensiero filosofico, i fantasmi della più alta poesia.. ${ }^{8}$ The 'fantasmi della più alta poesia' element in this way of putting it, touching as it does upon the power of poetry properly or at least persuasively to signify in the area of theology, raises as many issues as it resolves, but in respect of what matters here - namely the nature of Dante's dealings with his auctores in general and with Thomas in particular - the formula is unexceptionable.

Etienne Gilson, whose work as a historian of medieval thought consistently, though not uncritically, complements that of Nardi, is similarly preoccupied by the problem of over-interpretation, by the need come what may to accredit Dante by way of Aquinas, an issue he pursues, however, by way pre-eminently of otherness and eccentricity, of what from a strictly Thomist point of view amounts to too ready an inclination in Dante to interrupt the continuity of human activity in time and eternity in favour of moral and intellectual finalities open to accomplishment here and now. ${ }^{9}$ The

lines 67-69 of Canto XIII. And that's not all, for the Averroes passage cited by Dante is not, in fact, in the De substantia orbis, but in the commentary on the Metaphysics, and runs thus: "All proportions and forms are in potential in prime matter and in act in the first mover." There is no 'idealiter' here, Dante, citing according to his sense of the passage and without the text to hand, adding it all the better to bring out its meaning. Thomas too cites this passage in Book II of the Sentences for the purpose of proving the existence of ideas in God (Saggidifilosofia (note 3 above), p. 347).

${ }^{7}$ Ibid., p. 379: 'Il Parodi, in un benevolo cenno di coserelle mie, mi accusa garbatamente di tirare l'acqua, trattando della filosofia di Dante, al mio "mulino antitomistico".'

${ }^{8}$ Neither for Thomas nor against Thomas, Dante proceeds on an ample eclectic basis to gather up all he needs by way of philosophical substance and inspiration from the rich arsenal of scholasticism, excluding as he does so no tradition; and all this he refashions by way of his own personal reflection in the crucible of his mind, the crucible from which proceed, philosophically tempered, the most exalted flights of poetic imagination (ibid., pp. 379-80).

${ }^{9}$ On Gilson as a Jantista, Etienne Gilson's letters to Bruno Nardi, ed. P. Dronke (Tavarnuzze (Florence): Galluzzo, 1998); S. Toussaint, 'Dante tra neoscolastica e teologia poetica: 
pattern is indeed a recognizable one, Dante's, in respect both of cognition and of appetition, being a tendency to interrupt the flow of human experience under the aspect both of time alone and of time and eternity taken together in favour of its successive instants, of points of arrival along the way; so, for example, as regards cognition, these lines from Book IV of the Convivio (xiii.12) with their sense of human intellection as but a movement from one peak of understanding to the next:

A la questione rispondendo, dico che propriamente crescere lo desiderio de la scienza dire non si può, avvegna che, come detto è, per alcuno modo si dilati. Ché quello che propriamente cresce, sempre è uno: lo desiderio de la scienza non è sempre uno, ma è molti, e finito l'uno, viene l'altro; sì che, propriamente parlando, non è crescere lo suo dilatare, ma successione di picciola cosa in grande cosa. Che se io desidero di sapere li principii de le cose naturali, incontanente che io so questi, è compiuto e terminato questo desiderio. E se poi io desidero di sapere che cosa e com'è ciascuno di questi principii, questo è un altro desiderio nuovo, né per l'avvenimento di questo non mi si toglie la perfezione a la quale mi condusse l'altro; e questo cotale dilatare non è cagione d'imperfezione, ma di perfezione maggiore. Quello veramente de la ricchezza è propriamente crescere, ché è sempre pur uno, sì che nulla successione quivi si vede, e per nullo termine e per nulla perfezione. ${ }^{10}$

Curtius, Maritain, Maurras, Gilson', in Dante e la cultura del suo tempo. Dante e le culture dei confini. Atti del Convegno Internazionale di Studi Danteschi, Gorizia, ottobre 1997 (Gorizia: Società Dante Alighieri (Fondazione Cassa di Risparmio di Gorizia), 1999), pp. 81-90; C. Marabelli, 'Etienne Gilson e Dante', in Medievalie medievisti. Saggi su aspetti del Medioevo teologico e della sua interpretazione (Milan: Jaca Book, 2000), pp. 243-48. On Gilson generally, L. K. Shook, Etienne Gilson (Toronto: Pontifical Institute of Mediaeval Studies, 1984). In Gilson himself, Dante and Philosophy, trans. D. Moore (New York: Harper and Row, 1963; originally Dante et la philosophie, Paris: Vrin, 1939; in Italian, Dante e la filosofia, ed. C. Marabelli, (Milan: Jaca Book, 1987)); 'Dante's Notion of a Shade: Purgatorí XXV', Medieval Sudies 29 (1967), 14-42 (also in Dante. The Critical Complex, 8 vols, ed. R. Lansing (New York and London: Routledge, 2003), vol. 3, pp. 340-58); 'Dante's Mirabile Visione', Cornell Library Journal 5 (1968), 1-17; Dante et Béatrice: études dantesques (Paris: Vrin, 1974), with an Italian translation ed. B. Garavelli (Milan: Medusa, 2004); 'Dante, la filosofia e la politica', Cultura e libri 57 (1990), 56-60; 'Dante's Place in History', in Critical Essays on Dante, ed. G. Mazzotta (Boston: G. K. Hall, 1991), pp. 119-39. On Thomas, and apart from Le Thomisme: introduction à la philosophie de saint Thomas J'Aquin (5th and 6th edn Paris: Vrin, 1947 and 1965 respectively; originally 1919) and its many reprints both of the original and in translation, The Elements of Christian Philosopby (New York: Doubleday, 1960). For a general bibliography, Etienne Gilson: a bibliograpby / une bibliographie (The Etienne Gilson Series, 3), ed. M. McGrath (Toronto: Pontifical Institute of Medieval Studies, 1982).

${ }^{10} \mathrm{My}$ response to the difficulty is as follows. The desire for knowledge cannot be said to grow in the strict sense, although, as I have shown, it broadens out in a certain way. Whatever grows in the strict sense always remains a single entity. The desire for knowledge does not remain a single entity. It is multiple, and when one desire is satisfied 
while as regards appetition, these from Book III (xv.7-10) designed to secure in the wake of a now soaring spirituality a species of philosophical wisdom, and thus of philosophical happiness, proportionate to those 'many men and women in this language of ours burdened by domestic and civic care' but anxious in respect of their proper humanity, of what it might mean to be as a creature of adult accountability:

Veramente può qui alcuno forte dubitare come ciò sia, che la sapienza possa fare l'uomo beato, non potendo a lui perfettamente certe cose mostrare; con ciò sia cosa che 'l naturale desiderio sia a l'uomo di sapere, e sanza compiere lo desiderio beato essere non possa. A ciò si può chiaramente rispondere che lo desiderio naturale in ciascuna cosa è misurato secondo la possibilitade de la cosa desiderante: altrimenti andrebbe in contrario di sé medesimo, che impossibile è; e la Natura l'avrebbe fatto indarno, che è anche impossibile. In contrario andrebbe: ché, desiderando la sua perfezione, desiderrebbe la sua imperfezione; imperò che desiderrebbe sé sempre desiderare e non compiere mai suo desiderio (e in questo errore cade l'avaro maladetto, e non s'accorge che desidera sé sempre desiderare, andando dietro al numero impossibile a giungere). Avrebbelo anco la Natura fatto indarno, però che non sarebbe ad alcuno fine ordinato. E però l'umano desiderio è misurato in questa vita a quella scienza che qui avere si può, e quello punto non passa se non per errore, lo quale è di fuori di naturale intenzione. E così è misurato ne la natura angelica, e terminato, in quanto, in quella sapienza che la natura di ciascuno può apprendere. E questa è la ragione per che li Santi non hanno tra loro invidia, però che ciascuno aggiugne lo fine del suo desiderio, lo quale desiderio è con la bontà de la natura misurato. Onde, con ciò sia cosa che conoscere di Dio e di certe altre cose quello esse sono non sia possibile a la nostra natura, quello da noi naturalmente non è desiderato di sapere. E per questo è la dubitazione soluta. ${ }^{11}$

another comes into being, so that, in the broadening out of the desire for knowledge, growth, strictly speaking, does not occur; rather, what happens is that something small is successively replaced by something large. For instance, if I desire to know the constitutive principles of physical objects, this desire is fulfilled and brought to completion as soon as I know what these principles are. If I then desire to know with respect to each of these principles how it is composed, and what are its sources, this is another and distinct desire. Further, the occurrence of this new desire does not deprive me of the perfection gained through fulfilling the first desire. Such broadening out does not cause imperfection. In the case of the desire for riches, by contrast, what occurs is growth in the strict sense, since the desire always remains one and the same thing: one entity is replaced by another, since nothing comes to completion and no perfection is attained.

${ }^{11}$ However, at this point a person may seriously wonder how it can be that wisdom can make man happy, if it cannot perfectly show certain things to him, since the natural desire of man is to know, and he cannot be happy unless that desire is satisfied. To this, the clear answer can be given that the natural desire in everything is in accordance with the 
Throughout, then, the pattern is the same, Dante, with respect both to knowing and to willing, being inclined to construe these things successionally or in terms of an ideal progression from one qualitatively distinct moment to the next. Gilson, however, pursues the idea on the basis, not of these, but of two other passages pointing in the same direction, namely Conv. II.xiv.14-18 as touching on ethics rather than metaphysics as (theology apart) the human science par excellence, and Mon. III.xvi.7-8 as touching on the complementarity of philosophy and theology as the means respectively to mortal and immortal happiness, each of these passages, he thinks, testifying to this same preoccupation, less with understanding in the round, than with the completeness of the cognitive instance. First, then, on ethics as the ground of human happiness this side of death, the Convivio passage, secure in its sense of moral science as the architectonic or organizational science in human experience and of the authorization of this position both in Thomas and in the Philosopher:

Lo Cielo cristallino, che per Primo Mobile dinanzi è contato, ha comparazione assai manifesta a la Morale Filosofia; ché Morale Filosofia, secondo che dice Tommaso sopra lo secondo de l'Etica, ordina noi a l'altre scienze. Che, sì come dice lo Filosofo nel quinto de l'Etica, 'la giustizia legale ordina la scienze ad apprendere, e comanda, perché non siano abbandonate, quelle essere apprese e ammaestrate'; e così lo detto cielo ordina col suo movimento la cotidiana revoluzione

capacity of the thing which desires; otherwise the thing would strive in a fashion contrary to its own being, which is impossible; and Nature would have made it in vain, which is also impossible. It would strive in a self-contrary fashion, for in desiring its own perfection it would desire its own imperfection, because it would desire always to be desiring and never to satisfy its own desire (which is the error into which the accursed miser falls: he does not recognize that he desires always to be desiring, in striving after a number impossible to reach). Also, Nature would have made it in vain, because it would not be directed to any end. Human desire, consequently, is measured in this life in accordance with that knowledge which can be gained here, and never passes that point except in error, which is something foreign to the intention of nature. In the angelic nature desire is likewise measured, and is limited precisely to that wisdom which the nature of each is capable of apprehending. It is for this reason, too, that the saints do not envy each other, for each attains the end of his own desire, and this desire is commensurate with the quality of his goodness. Since, then, it is impossible for our nature to know of God what He is (the same holds true of certain other things), this is not something which we naturally desire to know. In this way the difficulty is resolved. For the 'many men and women in this language of ours' element of the argument, Conv. I.ix.5 and i.4: 'e questi nobili sono principi, baroni, cavalieri, e molt'altra nobile gente, non solamente maschi ma femmine, che sono molti e molte in questa lingua, volgari, e non litterati ... Di fuori da l'uomo possono essere similemente due cagioni intese, l'una de le quali è induttrice di necessitade, l'altra di pigrizia. La prima è la cura familiare e civile, la quale convenevolmente a sé tiene de li uomini lo maggior numero, sì che in ozio di speculazione esser non possono.' 
di tutti li altri, per la quale ogni die tutti quelli ricevono [e mandano] qua giù la vertude di tutte le loro parti. Che se la revoluzione di questo non ordinasse ciò, poco di loro vertude qua giù verrebbe o di loro vista. Onde ponemo che possibile fosse questo nono cielo non muovere, la terza parte del cielo sarebbe ancora non veduta in ciascun luogo de la terra; e Saturno sarebbe quattordici anni e mezzo a ciascuno luogo de la terra celato, e Giove sei anni quasi si celerebbe, e Marte uno anno quasi, e lo Sole centottantadue dì e quattordici ore (dico dì, cioè tanto tempo quanto misurano cotanti dì), e Venere e Mercurio quasi come lo Sole si celerebbe e mosterrebbe, e la Luna per tempo di quattordici dì e mezzo, starebbe ascosa ad ogni gente. $\mathrm{E}$ da vero non sarebbe qua giù generazione né vita d'animale o di piante: notte non sarebbe né die, né settimana né mese né anno, ma tutto l'universo sarebbe disordinato, e lo movimento de li altri sarebbe indarno. E non altrimenti, cessando la Morale Filosofia, l'altre scienze sarebbero celate alcuno tempo, e non sarebbe generazione né vita di felicitade, e indarno sarebbero scritte e per antico trovate. Per che assai è manifesto, questo cielo [in] sé avere a la Morale Filosofia comparazione. ${ }^{12}$

${ }^{12}$ The crystalline heaven, described as the first moving body in the account given above, is quite clearly similar to moral philosophy, because, as Thomas says in his commentary on the second book of the Ethice, moral philosophy directs us towards the other sciences. For, as the Philosopher states in the fifth book of the Ethics, "civic justice directs that the sciences be learned in due order, and, to ensure that they never be abandoned, commands that they be both learned and taught"; similarly the heaven just mentioned directs with its movement the daily revolution of all the others, by which means all those heavens every day receive and communicate to our world below the power invested in their every part, for if the revolution of this heaven did not direct this, little of their power would come down to our world below, and we would have little sight of them. Consequently, in the hypothetical case that this ninth heaven did not move, a third of the heaven of the stars would not yet have been seen from any place on earth; Saturn would be hidden from every place on earth for fourteen and a half years; Jupiter would be hidden for almost six years, Mars for almost a year, the Sun for one hundred and eighty two days days and fourteen hours. Venus and Mercury would be hidden and be visible for much the same time as the Sun, and the Moon would remain concealed from all mankind for fourteen and a half days. And indeed in this world below, plant and animal life would neither be generated nor continue; there would be neither night nor day, no weeks, months or years, and in fact the whole universe would be thrown into disorder, and the movement of other heavens would be in vain. In the same way, should moral philosophy disappear, the other sciences would be hidden for some time, the life of happiness would neither be generated nor continue, and it would have been in vain that the sciences were discovered in ancient times and committed to writing. It is quite clear, then, that this heaven has a similarity to moral philosophy. Thomas (In eth. II, lect. 1, note 1), tracing the structure of the second book of the Ethics, has 'Prima autem pars dividitur in partes duas: in prima determinat de virtutibus moralibus. In secunda de intellectualibus, in sexto libro, ibi; quia autem existimus prius dicentes et cetera. Et ratio ordinis est, quia virtutes morales sunt magis notae, et per eas disponimur ad intellectuales.' For Thomas on iustitia legalis and the common good, V, lect. 3, but the form of Dante's argument suggests I, lect. 2, n. 9: 
Gilson, alarmed by Dante's commitment to ethics pure and simple - to ethics as untouched by theology - as the ground of human well-being here and now, lets it pass for the moment, contenting himself instead with some remarks relative to his, Thomistically speaking, no less strange promotion of ethics over metaphysics in the order of scientific excellence: 'at the risk', he says, 'of slightly stretching Dante's thought, but with the object of bringing out what seems to me the idea which a great number of passages suggest, I am going to say, in definitely stating that the formula is not his, that metaphysics as conceived by Dante remains in itself the loftiest and most perfect of the sciences, but that it is not so as far as we are concerned.'. ${ }^{3}$ But by the time we reach the Monarchia he is more resolute, more intent on pointing up the damage done to the fabric of Christian wisdom, and thus of Christendom itself, by what amounts to Dante's effrontery at this point, to his indifference to the seamlessness of it all. The offending text reads thus:

Duos igitur fines providentia illa inenarrabilis homini proposuit intendendos: beatitudinem scilicet huius vite, que in operatione proprie virtutis consistit et per terrestrem paradisum figuratur; et beatitudinem vite ecterne, que consistit in fruitione divini aspectus ad quam propria virtus ascendere non potest, nisi lumine divino adiuta, que per paradisum celestem intelligi datur. Ad has quidem beatitudines, velut ad diversas conclusiones, per diversa media venire oportet. Nam ad primam per phylosophica documenta venimus, dummodo illa sequamur secundum virtutes morales et intellectuales operando; ad secundam vero per documenta spiritualia que humanam rationem transcendunt, dummodo illa sequamur secundum virtutes theologicas operando, fidem spem scilicet et karitatem. ${ }^{14}$

'Sed scientiae speculativae praecipit civilis solum quantum ad usum, non autem quantum ad determinationem operis; ordinat enim politica, quod aliqui doceant vel addiscant geometriam. Huiusmodi enim actus inquantum sunt voluntarii pertinent ad materiam moralem et sunt ordinabiles ad finem humanae vitae. Non autem praecipit politicus geometrae quid de triangulo concludat, hoc enim non subiacet humanae voluntati, nec est ordinabile humanae vitae, sed dependet ex ipsa rerum ratione. Et ideo dicit, quod politica praeordinat quas disciplinarum debitum est esse in civitatibus, scilicet tam practicarum quam speculativarum, et quis quam debeat addiscere, et usque ad quod tempus.' Also note 11: 'Et dicit quod, cum politica, quae practica est, utatur reliquis practicis disciplinis, sicut secundo dictum est, et cum ipsa legem ponat quid oporteat operari et a quibus abstinere, ut primo dictum est, consequens est quod finis huius tamquam architectonicae complectitur, idest subse continet fines aliarum scientiarum practicarum.'

${ }^{13}$ Dante and Philosophy cit. (note 9 above), p. 122 (italics original).

${ }^{14}$ Ineffable providence has thus set before us two goals to aim at; i.e. happiness in this life, which consists in the exercise of our own powers and is figured in the earthly paradise; and happiness in the eternal life, which consists in the enjoyment of the vision of God (to which our own powers cannot raise us except with the help of God's light) 
- at which point Gilson, a shade rhetorically (for neither 'shattering' nor 'striking' forms part either of Dante's logic or of his lexis in this final chapter of the Monarchia), notes that, just as by way of his separating out Church and Empire Dante splits the Christian world into two camps, so also, by way of separating out philosophy and theology, he 'completely shatters the unity of Christian wisdom, the unifying principle and the bond of Christendom. In each of these vital matters this alleged Thomist struck a mortal blow at the doctrine of St Thomas Aquinas'. ${ }^{15}$ Rhetoric aside, however, the formula is again unexceptionable; for though, as Gilson insists, there is hardly sufficient here to align him with the more radical philosophical spirits of his time, with those committed to the notion of a double order of truth in the world, there is more than enough to mark him out from Thomas and from the rhythm of specifically Thomist spirituality, from a way of seeing and understanding the human situation attuned to ulteriority rather than to periodicity as the means of its interpretation.

Temperamentally as well as by profession Kenelm Foster lived in the company of one whom he believed to be incomparably gifted in point both of holiness and of erudition, of one who offered a perfect example of how to be a Christian in - as Kenelm himself used to say - the Dominican way of being a Christian. ${ }^{16}$ And this, he thought, this special combination of

and which is signified by the heavenly paradise. Now these two kinds of happiness must be reached by different means, as representing different ends. For we attain the first through the teachings of philosophy, provided that we follow them putting into practice the moral and intellectual virtues; whereas we attain the second through spiritual teachings which transcend human reason, provided that we follow them putting into practice the theological virtues, namely faith, hope and charity.

${ }^{15}$ Dante and Philosopby cit. (note 9 above), p. 212.

${ }^{16}$ K. Foster, O.P., The Mind in Love, Aquinas Society of London, Aquinas paper no. 25 (London: Blackfriars, 1956); God's Tree: Essays on Dante and Other Matters (London: Blackfriars, 1957), with, at pp. 141-49, an essay entitled 'The Tact of St Thomas'; 'Religion and Philosophy in Dante', in The Mind of Dante (Cambridge: Cambridge University Press, 1965), pp. 47-78 (subsequently in Dante. The Critical Complex, 8 vols, ed. R. Lansing (New York and London: Routledge, 2003), vol. 6, pp. 113-44); 'Tommaso d'Aquino', in the Enciclopedia Jantesca, 6 vols (Rome: Istituto della Enciclopedia Italiana, 1970-76), vol. 5, pp. 626-49; Dante e San Tommaso (Rome: Casa di Dante, 1975; lecture of 17 November, 1974 at the Casa di Dante in Rome); The Two Dantes and Other Studies (London: Darton, Longman and Todd, 1977), with, at pp. 56-65, 'St Thomas and Dante'; 'Purgatorio XXII', in Cambridge Readings in Dante's Comedy, ed. K. Foster and P. Boyde (Cambridge: Cambridge University Press, 1981), pp. 138-54; 'Dante's Idea of Purgatory, with Special Reference to Purgatorio XXI.58-66', in Dies Illa. Death in the Middle Ages (Proceedings of the 1983 Manchester Colloquium), ed. J. H. M. Taylor (Liverpool: Cairns, 1984), pp. 97106; 'Dante and Two Friars: Paradiso XI-XII', New Blackfriars 66 (1985), 480-96 (and, in a revised form, as 'Gli elogi danteschi di san Francesco e di san Domenico', in Dante e il francescanesimo (Lectura Dantis Metelliana) (Cava di Tirreni: Avagliano, 1987), pp. 229-49). Also (ed. and trans.), The Life of Saint Thomas Aquinas: Biographical Documents 
piety and precision, was what Dante too saw in him. What Dante saw in Thomas, Kenelm thought, was the power to structured consciousness, to an orderly expression of the idea in all the complexity of the idea; so, for example, on intellectual discretion and, implicitly, Thomas as exemplary in this area, this passage from the Convivio at IV.viii.1: 'Lo più bello ramo che de la radice razionale consurga si è la discrezione. Ché, sì come dice Tommaso sopra lo prologo de l'Etica, "conoscere l'ordine d'una cosa ad altra è proprio atto di ragione", e è questa discrezione, ${ }^{17}$ a passage which, taken together with the "infiammata cortesia / di fra Tommaso e 'l discreto latino' moment of Par. XII.143-44, ${ }^{18}$ determines the shape and substance of the 'Con questa distinzion prendi 'I mio detto' sequence of Paradiso XIII as a hymn to the properties of the Thomist mind in act:

Non ho parlato sì, che tu non posse ben veder ch'el fu re, che chiese senno acciò che re sufficiente fosse;

non per sapere il numero in che enno

li motor di qua sù, o se necesse con contingente mai necesse fenno; non si est dare primum motum esse, o se del mezzo cerchio far si puote trïangol sì ch'un retto non avesse.

Onde, se ciò ch'io dissi e questo note, regal prudenza è quel vedere impari in che lo stral di mia intenzion percuote; e se al "surse" drizzi li occhi chiari, vedrai aver solamente respetto ai regi, che son molti, e ' buon son rari.

Con questa distinzion prendi 'l mio detto;

(London: Longmans, 1959), and, with P. Boyde, Dante's Lyric Poetry, 2 vols (Oxford: Clarendon Press, 1967). C. Ryan, 'Kenelm Foster on Dante', New Blackfriars 59 (1978), 187-92; M. Roddewig, 'In memorian Pater Kenelm Foster, O.P. (26.12.1910-6.2.1986)', in Mitteilungsblatt der deutschen Dante Gesellschaft (1986), 20; P. Boitani, 'Kenelm Foster: la mente innamorata', in Dante e la Bibbia. Atti del convegno internazionale promosso da 'Biblia', Firenze, 26-28 settembre 1986, ed. G. Barblan (Florence: Olschki, 1988), pp. 63-66; W. Wilson, 'Kenelm Foster', Lectura Dantio 8 (1991), 20-22.

${ }^{17}$ The fairest branch that springs from the root of reason is discretion, for, as Thomas says, commenting on the prologue to the Ethics, "To know how one thing is related to another is the distinctive act of reason", this being precisely what discretion is. Aquinas, In Eth. I. i, note 1: 'Sicut philosophus dicit in principio metaphysicae, sapientis est ordinare. Cuius ratio est, quia sapientia est potissima perfectio rationis, cuius proprium est cognoscere ordinem. Nam etsi vires sensitivae cognoscant res aliquas absolute, ordinem tamen unius rei ad aliam cognoscere est solius intellectus aut rationis'; $S c G$ I.i.2, etc.

${ }^{18}$ the glowing courtesy and the well-judged discourse of Brother Thomas ... 
e così puote star con quel che credi del primo padre e del nostro Diletto.

E questo ti sia sempre piombo a' piedi, per farti mover lento com' uom lasso e al sì e al no che tu non vedi:

ché quelli è tra li stolti bene a basso, che sanza distinzione afferma e nega ne l'un così come ne l'altro passo;

perch' elli 'ncontra che più volte piega l'oppinion corrente in falsa parte, e poi l'affetto l'intelletto lega.

Vie più che 'ndarno da riva si parte, perché non torna tal qual e' si move, chi pesca per lo vero e non ha l'arte.

$(\text { Par. XIII.94-123) })^{19}$

Thomas, then, for Dante, was a guide to the refined utterance, a mentor in the ways and means of truth under the aspect of articulation: 'Di qui, per concludere, la pressante raccomandazione suaccennata a chiunque si metta a "pescare per il vero", d'imparare con cura "l'arte" di pensare, per conoscere dove affermare e dove dubitare, prima di pronunciarsi su materie difficili. L'Aquinate dantesco è un educatore. ${ }^{20}$ At the same time, however, there is discernible here a pattern of divergence, an independence of spirit and of leading emphasis in just about every area of concern. Cosmologically, then, there is little in Aquinas to encourage Dante in his - from a Thomist point

${ }^{19}$ I have not so spoken that you cannot plainly see that he was a king, who asked for wisdom, in order that he might be a worthy king; not to know the number of the mover spirits here above, nor if necesse with a contingent ever made necesse; nor siest dare primum motum esse; nor if in a semicircle a triangle can be so constructed that it shall have no right angle. Wherefore, if you note this along with what I said, kingly prudence is that peerless vision on which the arrow of my intention strikes. And if to 'rose' you turn your discerning eyes, you will see it has respect only to kings - who are many and the good are rare. Take my words with this distinction, and they can stand thus with what you believe of the first father and of our beloved. And let this ever be as lead to your feet, to make you slow, like a weary man, in moving either to the yes or the no which you see not; for he is right low down among the fools, alike in the one and in the other case, who affirms or denies without distinguishing; because it happens that oftentimes hasty opinion inclines to the wrong side, and then fondness for it binds the intellect. Far worse than in vain does he leave the shore (since he returns not as he puts forth) who fishes for the truth and has not the art.

${ }^{20}$ Hence, to conclude, the above advice to anyone about to 'go fishing for the truth' to the effect that he should master carefully the 'art' of thinking, of knowing when to affirm and when to hold back, before pronouncing on difficult matters. Dante's Aquinas, in short, is an educator (Dante e San Tommaso, note 16 above, p. 19). 
of view - extravagant commitment to secondary causality as the means of divine purposefulness in the world, ${ }^{21}$ while metaphysically Dante reflects but faintly Thomas's preoccupation with the Pentateuchal I AM as a basis for something approaching a revolution in respect of every kind of ancient essentialism, every antique preference for whatness as distinct from thereness as an object of concern. ${ }^{22}$ And what applies in the area of cosmology and metaphysics applies also in that of anthropology and psychology; for if Dante's is a sense of the rational soul as the entelechy or formal principle

${ }^{21}$ Conv. III.vi.5: 'e però che Dio è universalissima cagione di tutte le cose, conoscendo lui, tutte le cose conosce in sé, secondo lo modo de la Intelligenza. Per che tutte le Intelligenze conoscono la forma umana, in quanto ella è per intenzione regolata ne la divina mente; e massimamente conoscono quella le Intelligenze motrici, però che sono spezialissime cagioni di quella e d'ogni forma generale, e conoscono quella perfettissima, tanto quanto essere puote, sì come loro regola ed essemplo'; Par. II.121-23: 'Questi organi del mondo così vanno, / come tu vedi omai, di grado in grado, / che di sù prendono e di sotto fanno'; VII.130-38: 'Li angeli, frate, e 'l paese sincero / nel qual tu se', dir si posson creati, / sì come sono, in loro essere intero; / ma li alimenti che tu hai nomati / e quelle cose che di lor si fanno / da creata virtù sono informati. / Creata fu la materia ch'elli hanno; / creata fu la virtù informante / in queste stelle che 'ntorno a lor vanno.' Thomas, $S_{c} G$ III.lxvi.6: 'Secundum ordinem causarum est ordo effectuum. Primum autem in omnibus effectibus est esse: nam omnia alia sunt quaedam determinationes ipsius. Igitur esse est proprius effectus primi agentis, et omnia alia agunt ipsum inquantum agunt in virtute primi agentis. Secunda autem agentia, quae sunt quasi particulantes et determinantes actionem primi agentis, agunt sicut proprios effectus alias perfectiones, quae determinant esse'; $S T$ Ia.65.4 resp.: 'Et ideo, cum simile fiat a suo simili, non est quaerenda causa formarum corporalium aliqua forma immaterialis; sed aliquod compositum, secundum quod hic ignis generatur ab hoc igne. Sic igitur formae corporales causantur, non quasi influxae ab aliqua immateriali forma, sed quasi materia reducta de potentia in actum ab aliquo agente composito', etc. A. Mellone, O.F.M., La dottrina di Dante Alighierisulla prima creazione (Salerno: Convento S. Maria degli Angeli, 1950, and in Saggi e letture Jantesche. Lectura Dantis Metelliana (Angri (Salerno): Editrice Gaia, 2005), pp. 21-87); idem, 'Emanatismo neoplatonico di Dante per le citazioni del Liber de Causis', Divus Thomas 54 (1951), 205-12; idem, 'Il concorso delle creature nella produzione delle cose secondo Dante', Divus Thomas 56 (1953), 273-86, and in Saggie letture dantesche cit., pp. 89-110; idem, 'Il canto XXIX del Paradiso', in Nuove letture dantesche (Casa di Dante, Roma), 7 (Florence: Le Monnier, 1974), 193-213 (subsequently in Saggi e letture dantesche cit., pp. 157-74, with the title 'Il canto XXIX del Paradiso. (Una lezione di angelologia)'); B. Nardi, 'Il canto XXIX del Paradiso', Convivium 24 (1956), 294-302; S. Bemrose, Dante's Angelic Intelligences. Their Importance in the Cosmos and in Pre-Christian Religion (Rome: Edizioni di Storia e Letteratura, 1983).

${ }^{22}$ K. Foster, O.P., Dante e San Tommaso cit. (note 16 above), p. 11, with reference both to Thomas (ST Ia 3.4; $S c G$ I.xxii and xxviii, etc.) and E. Gilson (Le Thomisme (note 9 above), pp. 44-58, 515-18): 'A simile conclusione ci porterebbe, io credo, un accurato confronto ... fra lo scarso uso che fa Dante del termine "esse", o "essere", in senso filosofico, e l'uso diffusissimo e personalissimo che ne fa Tommaso - al segno che questo dell'"esse”, ossia dell'“actus essendi", può chiamarsi il vero e proprio concetto chiave della sua metafisica, quello per cui (secondo Tommaso) meglio si coglie e si misura e la realtà intrinseca di ogni cosa ed i suoi rapporti con Dio, il quale appunto è l'“ipsum esse subsistens", e perciò l'unica sorgente dello "esse" di qualsiasi cosa.' 
of the psychosomatic whole in man, then the Convivio testifies on more than one occasion to something closer to the pneumatic, to a sense of the soul as a spiritual entity captive pro tempore to the flesh ${ }^{23}$ and if Dante's is a sense of the empirical and abstractive mechanism of properly human intellection, he, unlike Thomas, is inclined to opt for the possible rather than for the active intellect as the principle of specifically human being. ${ }^{24}$ Clearly, the argument requires - and in Kenelm always enjoys - careful statement, Dante's, again, being a virtually unqualified admiration for Thomas as the embodiment of Christian-theological wisdom and sanctity ("nel santo dottore il genio di Dante percepiva e ammirava qualcosa di ben altrimenti personale e profondo; voglio dire, una certa combinazione d'intelligenza e di santità, tal che le stesse sue qualità di forza e di finezza intellettuale fossero insieme riflesso e espressione di probità morale') $;{ }^{25}$ but for all that,

${ }^{23}$ Conv. III.ii.14: 'però che l'anima è tanto in quella sovrana potenza nobilitata e dinudata da materia, che la divina luce, come in angelo, raggia in quella'; vii. 5 'Così la bontà di Dio è ricevuta altrimenti da le sustanze separate, cioè da li Angeli, che sono sanza grossezza di materia, quasi diafani per la purità de la loro forma, e altrimenti da l'anima umana, che, avvegna che da una parte sia da materia libera, da un'altra è impedita, sì come l'uomo ch'è tutto ne l'acqua fuor del capo, del quale non si può dire che tutto sia ne l'acqua né tutto fuor da quella; e altrimenti da li animali, la cui anima tutta in materia è compresa, ma alquanto è nobilitata; e altrimenti da le piante, e altrimenti da le minere; e altrimenti da la terra che da li altri [elementi], però che è materialissima, e però remotissima e improporzionalissima a la prima simplicissima e nobilissima vertude, che sola è intellettuale, cioè Dio', etc. Aquinas, by contrast, $S_{c} G$ II.lxviii (a chapter variously interesting from the point of view of the Convivio): 'Si enim substantia intellectualis non unitur corpori solum ut motor, ut Plato posuit, neque continuatur ei solum per phantasmata, ut dixit Averroes, sed ut forma; neque tamen intellectus quo homo intelligit, est praeparatio in humana natura, ut dixit Alexander; neque complexio, ut Galenus; neque harmonia, ut Empedocles; neque corpus, vel sensus, vel imaginatio, ut antiqui dixerunt: relinquitur quod anima humana sit intellectualis substantia corpori unita ut forma' (2); ST Ia.76.1 resp. etc.

${ }^{24}$ Mon. I.iii.6-7: 'sed esse apprehensivum per intellectum possibilem ... Patet igitur quod ultimum de potentia ipsius humanitatis est potentia sive virtus intellectiva', à propos of which K. Foster, O.P., Dante e San Tommaso (note 16 above), pp. 10-11: 'E mi sembra molto significativo che quando Dante vuol dare, nella Monarchia, una definizione precisa dell'agire umano in quanto tale, tira in campo solo lo "intellectus possibilis", asserendo che il "constitutivum spetiei" dell'uomo è "esse apprehensivum per intellectum possibilem" formula inconcepibile in bocca a sanTommaso, ma a cui avrebbe potuto sottoscrivere benissimo un filosofo così lontano dal tomismo come fu, ad esempio, il francescano inglese Roger Bacon. Insomma, l'assenza totale d"“intellectus agens" dal lessico di Dante è argomento piuttosto forte contro il suo tomismo.' Aquinas, $S_{c} G$ II.lxxvi.20: 'Operatio autem propria hominis est intelligere: cuius primum principium est intellectus agens, qui facit species intelligibiles, a quibus patitur quodammodo intellectus possibilis, qui factus in actu, movet voluntatem'; ST Ia.79.3, etc.

25 in the saintly doctor Dante in his wisdom saw and admired something far more personal and profound, by which I mean a certain combination of intelligence and 
there is no disguising the otherness of Dante's thinking with respect to the ipse dixit of the master, his willingness for the sake of an alternative spirituality to embrace the alternative solution.

3. By the time, then, of Kenelm Foster's initiative the myth of Dante's Thomism - certainly if by this we mean anything approaching a sense of his systematic espousal of Thomist positions in key areas of moralphilosophical, natural-philosophical and theological concern - had been laid. Fashioned by a desire to claim the text for Thomas and for Thomism as normative in the area of Christian-theological understanding, it had gradually been dismantled in favour of something closer to contrast than to continuity as the hallmark of a relationship nonetheless decisive for Dante's emergence as a philosophical and theological spirit. But for all the power and persuasiveness of the argument so far, there is still a way to go; for to live with the question of Dante and Aquinas is to be impressed by two things: (a) by the way in which it stands to be proposed in terms, not so much of the what, as of the bow of Dante's reading of Thomas, not so much of the substance as of the psychology of that reading, and (b) by the notion that, mediated as it is by the problematics of existence as verified by the subject of that existence, Dante's, vis-à-vis that of Aquinas, is a revised sense of the theological project in its essential shape and structure. As far, then, as the first of these things is concerned we may begin by saying that, in a manner apt to defy the mathematics of the case - just five references in all, four in the Convivio and one in the Monarchia ${ }^{26}$ - Thomas

holiness, such that these selfsame qualities of strength and intellectual finesse were in one and the same moment a reflection and an expression of moral integrity (Dante e San Tommaso, note 16 above, p. 17).

${ }^{26}$ Conv. IV.xv.12: 'Ché, secondo la malizia de l'anima, tre orribili infermitadi ne la mente de li uomini ho vedute. L'una è di naturale jattanza causata: ché sono molti tanto presuntuosi, che si credono tutto sapere, e per questo le non certe cose affermano per certe; lo qual vizio Tullio massimamente abomina nel primo de li Offici e Tommaso nel suo Contra-li-Gentili, dicendo: "Sono molti tanto di suo ingegno presuntuosi, che credono col suo intelletto poter misurare tutte le cose, estimando tutto vero quello che a loro pare, falso quello che a loro non pare"' ( $S_{c} G$ I.v.4: 'Sunt enim quidam tantum de suo ingenio praesumentes ut totam rerum naturam se reputent suo intellectu posse metiri, aestimantes scilicet totum esse verum quod eis videtur et falsum quod eis non videtur'); Conv. IV.xxx.3: 'Dico adunque: Contra-li-erranti mia. Questo Contra-li-erranti è tutto una parte, e è nome d'esta canzone, tolto per essemplo del buono frate Tommaso d'Aquino, che a un suo libro, che fece a confusione di tutti quelli che disviano da nostra Fede, puose nome Contra li Gentili'; Mon. II.iv.1: 'sicut dicit Thomas in tertio suo contra Gentiles, miraculum est quod preter ordinem in rebus comuniter institutum divinitus fit' ( $S c G$ III. xcix.2: 'Potest autem Deus praeter hunc ordinem facere: ut scilicet ipse effectum aliquem in inferioribus operetur, nihil ad hoc agente superiori agente'). For the commentary on the Ethics, Conv. II.xiv.14: 'Lo Cielo cristallino, che per Primo Mobile dinanzi è contato, 
is everywhere discernible as that whereby Dante feels able to settle on the exact notional and expressive solution. Instances abound, but to take first the least complicated of them there is, for example, the 'oportet igitur ultimum finem universi esse bonum intellectus' of $S_{c} G$ I.i. $4^{27}$ for the 'ben de l'intelletto' of Inf. III.18 at the heart of his anthropology and ethic; ${ }^{28}$ or the 'ut ex hoc ad divinum amorem inflammarentur' of $S c G$ IV.lv.1329 for the 'Questo decreto, frate, sta sepulto / a li occhi di ciascuno il cui ingegno / ne la fiamma d'amor non è adulto' of Par. VII.58-60 at the heart of his soteriology; ${ }^{30}$ or the 'si aliquis non videret solem et lunam et alia astra' of $S_{c} G$ II.xcii. $9^{31}$ for the 'amor che move il sole e l'altre stelle' of Par. XXXIII.145 at the heart of his affective theology. ${ }^{32}$ Everywhere the pattern is the same, for everywhere it is a question of Thomas's functioning, not merely as a master or mentor, but as a friend or fellow traveller, as one co-involved at the point of precise understanding and exact expression. And what applies at the level of the merely phrasal, clausular or otherwise minimal syntactic unit applies also at the level of

ha comparazione assai manifesta a la Morale Filosofia; ché Morale Filosofia, secondo che dice Tommaso sopra lo secondo de l'Etica, ordina noi a l'altre scienze' (In eth. I, lect. 2, note 7: 'Optimus finis pertinet ad principalissimam scientiam, et maxime architectonicam. Et hoc patet ex his, quae supra praemissa sunt. Dictum est enim quod sub scientia vel arte quae est de fine continentur illae quae sunt circa ea quae sunt ad finem. Et sic oportet quod ultimus finis pertineat ad scientiam principalissimam, tamquam de principalissimo fine existentem, et maxime architectonicae, tamquam praecipienti aliis quid oporteat facere. Sed civilis scientia videtur esse talis, scilicet principalissima, et maxime architectonica. Ergo ad eam pertinet considerare optimum finem'); Conv. IV.viii.1: 'Lo più bello ramo che de la radice razionale consurga si è la discrezione. Ché, sì come dice Tommaso sopra lo prologo de l'Etica, "conoscere l'ordine d'una cosa ad altra è proprio atto di ragione”, e è questa discrezione' (In eth. I, lect. 1, note 1: 'Sicut philosophus dicit in principio metaphysicae, sapientis est ordinare. Cuius ratio est, quia sapientia est potissima perfectio rationis, cuius proprium est cognoscere ordinem ...').

${ }^{27}$ the ultimate end of the universe must therefore be the good of the intellect ...; cf. the 'bonum igitur intellectus etiam in cognitione mali consistit' of I.lxxi.4 and the 'nam verum est bonum intellectus et finis ipsius' of II.lxxxiv.4.

${ }^{28}$ [We have come to the place where you will see the wretched people who have lost] the good of the intellect.

${ }^{29}$ [First, indeed, because it was necessary for men to know the beneficence of the Incarnation] so as to be thereby inflamed in the divine love.

${ }^{30}$ This decree, brother, is buried from the eyes of everyone whose understanding is not matured within love's flame.

${ }^{31}$ [In the same way, a person who had not seen] the sun or the moon or the other stars [and had heard that they were incorruptible bodies, might call them by the names of these corruptible bodies ...].

${ }^{32}$ [Here power failed the lofty phantasy; but already my desire and my will were revolved, like a wheel that is evenly moved, by the] love which moves the sun and the other stars. 
the period as a whole, where again the original utterance is on hand, not so much to determine the Dantean initiative in its precise notional and linguistic complexion, as to free the reader for an independent movement of the mind; so, for example, in respect of these lines (1-12) from Purgatorio IV on the psychology of layered consciousness, on the binding and loosing of the soul in circumstances of intense concentration:

Quando per dilettanze o ver per doglie, che alcuna virtù nostra comprenda, l'anima bene ad essa si raccoglie, par ch'a nulla potenza più intenda; e questo è contra quello error che crede ch'un'anima sovr' altra in noi s'accenda.

E però, quando s'ode cosa o vede che tegna forte a sé l'anima volta, vassene 'l tempo e l'uom non se n'avvede;

ch'altra potenza è quella che l'ascolta, e altra è quella c'ha l'anima intera: questa è quasi legata e quella è sciolta. ${ }^{33}$

this passage from the Contra gentiles at II.lviii.10 on the referability of every movement of the mind to one and the same intellectual principle, to the rational soul as one and undivided in essence and operation:

Videmus autem quod diversae actiones animae impediunt se: cum enim una est intensa, altera remittitur. Oportet igitur quod istae actiones, et vires quae sunt earum proxima principia, reducantur in unum principium ... quae est anima. Relinquitur igitur quod omnes actiones animae quae sunt in nobis, ab anima una procedunt. Et sic non sunt in nobis plures animae. ${ }^{34}$

Here, certainly, it is a question of reading, reception and the subtle psychology thereof, for if on the one hand there is enough in Dante by way

${ }^{33}$ When through impression of pleasure or of pain, which some one of our faculties receives, the soul is entirely centred thereon, it seems that it gives heed to no other of its powers; and this is contrary to that error which holds that one soul above the other is kindled within us; and therefore when aught is heard or seen which holds the soul strongly bent to it, the time passes away and we perceive it not, for one faculty is that which notes it, and another that which possesses the entire soul, the latter as it were bound, the former free.

${ }^{34}$ Now we observe that the diverse actions of the soul hinder one another, for when one is intense another is remiss. Therefore, these actions and powers that are proximate principles must be referred to one principle ... which is the soul. It follows, then, that all the actions of the soul which are in us proceed from the one soul. Thus, there are not several souls in us. 
of sameness to suggest an element of positive borrowing (the 'questo è contra quello error che crede / ch'un'anima sovr' altra in noi s'accenda' of lines 5 and 6 for Thomas's 'Et sic non sunt in nobis plures animae', or the 'altra potenza è quella che l'ascolta, / e altra è quella c'ha l'anima intera' of lines 10 and 11 for Thomas's 'cum enim una est intensa, altera remittitur'), there is at the same time sufficient by way of otherness - Dante's proposal of the question in terms of distraction and temporality, of the waylaying of self by its own passing preoccupations - to confirm something more refined than this, namely, the function of the original utterance as a means of emancipation, as that whereby, far from being constrained by the text, the spirit is empowered in respect of a discourse uniquely and unmistakably its own. And what applies to this passage from the early part of the Purgatorio applies also to the love-meditation in the central part of the canticle, where again it is a question, less of authorization, than of formed friendship, of companionship as the means of laying hold of the idea and thus of self itself in its now - for the moment at least - settled disposition. The question here is one of astral determinism, of the role of the stars in making us what we are. If, then, as Dante is willing to allow, the stars do indeed have some part to play in the shaping of self, this can only ever be preliminary, their role being at best dispositive, a matter of readying the soul for the task of free moral choice; for man as man, he believes, is moved, not so much by those forces ranged over against him, be they ever so exalted, as by free will as that whereby he most commends himself to God (the 'e quel ch'e' più apprezza' of Par. V.21), ${ }^{35}$ his, therefore, being a nobler species of subjection, the kind of subjection amounting to perfect freedom. The key lines (XVI.58-84) run as follows:

"Lo mondo è ben così tutto diserto d'ogne virtute, come tu mi sone, e di malizia gravido e coverto;

ma priego che maddite la cagione, sì ch 'i' la veggia e ch'i' la mostri altrui; ché nel cielo uno, e un qua giù la pone".

Alto sospir, che duolo strinse in "uhi!", mise fuor prima; e poi cominciò: "Frate, lo mondo è cieco, e tu vien ben da lui.

Voi che vivete ogne cagion recate pur suso al cielo, pur come se tutto movesse seco di necessitate.

Se così fosse, in voi fora distrutto libero arbitrio, e non fora giustizia

${ }^{35}$ and that which he most prizes ... 
per ben letizia, e per male aver lutto.

Lo cielo i vostri movimenti inizia; non dico tutti, ma, posto ch'i' 'l dica, lume v'è dato a bene e a malizia, e libero voler; che, se fatica ne le prime battaglie col ciel dura, poi vince tutto, se ben si notrica.

A maggior forza e a miglior natura liberi soggiacete; e quella cria la mente in voi, che 'l ciel non ha in sua cura.

Però, se 'l mondo presente disvia, in voi è la cagione, in voi sì cheggia; e io te ne sarò or vera spia." 36

relative to which we may note the following extracts from the Contra gentiles at III.lxxxv.11 and 19-20:

Frustra etiam darentur leges et praecepta vivendi, si homo suarum electionum dominus non esset. Frustra etiam adhiberentur poenae et praemia bonis aut malis, ex quo non est in nobis haec vel illa eligere. His autem desinentibus, statim socialis vita corrumpitur. Non igitur homo est sic secundum ordinem providentiae institutus ut electiones eius ex motibus caelestium corporum proveniant ... Sciendum tamen est quod, licet corpora caelestia non sint directe causa electionum nostrarum quasi directe in voluntates nostras imprimentia, indirecte tamen ex eis aliqua occasio nostris electionibus praestatur, secundum quod habent impressionem super corpora ... Manifestum autem est, et experimento cognitum, quod tales occasiones, sive sint exteriores sive sint interiores, non sunt causa necessaria electionis: cum homo per rationem possit eis resistere vel obedire ... quia scilicet impressio

36 "The world is indeed as utterly deserted by every virtue as you declare to me, and pregnant and overspread with iniquity, but I beg you to point out to me the cause, so that I may see it and show it to men, for one places it in the heavens and another here below." He first heaved a deep sigh which grief wrung into an "Ah me!", and then began, "Brother, the world is blind, and truly you come from it! You who are living refer every cause upward to the heavens alone, as if they of necessity moved all things with them. If this were so, free will would be destroyed in you, and there would be no justice in happiness for good or grief for evil. The heavens initiate your movements - I do not say all of them, but given for the moment that that is what I am saying, a light is given you to know good and evil, and free will, which if it endure fatigue in its first battles with the heavens, afterwards, if it is well nurtured, it conquers completely. You lie subject, in your freedom, to a greater power and to a better nature, and that creates the mind in you which the heavens have not in their charge. Therefore if the present world goes astray, in you is the cause and in you let it be sought; and I shall now bear you true testimony in this." 
stellarum in pluribus sortitur effectum, qui non resistunt inclinationi quae est ex corpore; non autem semper in hoc vel in illo, qui forte per rationem naturali inclinationi resistit. ${ }^{37}$

Again, there is plenty here to sustain the critic in the more routine aspects of his calling, in the pinning down of Dante to his sources: Thomas's 'frustra etiam adhiberentur poenae et praemia bonis aut malis, ex quo non est in nobis haec vel illa eligere' for Dante's 'non fora giustizia / per ben letizia, e per male aver lutto', or Thomas's 'licet corpora caelestia non sint directe causa electionum nostrarum quasi directe in voluntates nostras imprimentia' for Dante's 'Lo cielo i vostri movimenti inizia; / non dico tutti ..., or Thomas's 'cum homo per rationem possit eis resistere vel obedire' for Dante's 'lume v'è dato a bene e a malizia, / libero voler'. But here too there is sufficient by way of difference - by way of Dante's reconfiguration and indeed re-substantiation of the text in point both of emphasis (the 'A maggior forza e a miglior natura / liberi soggiacete' moment of lines 79-81) and of expressivity (the 'duolo strinse in "uhi!"' moment of lines 64-66) - to encourage him in a sense of something at once more subtle and sublime than this, namely in a sense of the text as a principle of deliverance, as that whereby the receptive spirit is made equal at last to the matter in hand.

As a third example of textuality under the aspect of friendship we may take Dante's account in the Paradiso of the role of providence both in fashioning personality and in ensuring its proper functionality as an instrument of God's purposes in the world. If, then, nature, in the sense of natura naturans, does a good job in perpetuating the species, it is down to providence as operative through the stars that the individual is confirmed (a) in the fullness of his individuality, and (b) in his status as a means of divine intentionality:

${ }^{37}$ Besides, it would be useless for laws and rules of living to be promulgated if man were not master of his own choices. Useless, too, would be the employment of punishments and rewards for good or evil deeds, in regard to which it is not in our power to choose one or the other. In fact, if these things disappear, social life is at once corrupted. Therefore, man is not so established by the order of providence that his choices originate from the motions of the celestial bodies ... Yet we should note that, though celestial bodies are not directly the cause of our choices, in the sense of directly making impressions on our wills, some occasion for our choices may be indirectly offered by them, because they do make an impression on bodies ... Moreover, it is plain and well known by experience that such occasions, whether they are external or internal, are not the necessary cause of choice, since man is able, on the basis of reason, either to resist or obey them. But there are many who follow natural impulses, while but few, the wise only, do not take these occasions of acting badly and of following those natural impulses. 
Ond' elli ancora: "Or dì: sarebbe il peggio

per l'omo in terra, se non fosse cive?"

"Sì”, rispuos' io; "e qui ragion non cheggio".

E puot' elli esser, se giù non si vive

diversamente per diversi offici?

Non, se 'l maestro vostro ben vi scrive".

Sì venne deducendo infino a quici;

poscia conchiuse: "Dunque esser diverse

convien di vostri effetti le radici:

per ch'un nasce Solone e altro Serse,

altro Melchisedèch e altro quello

che, volando per l'aere, il figlio perse.

La circular natura, ch'è suggello

a la cera mortal, fa ben sua arte, ma non distingue l'un da l'altro ostello.

Quinci addivien ch'Esaù si diparte per seme da Iacòb; e vien Quirino da sì vil padre, che si rende a Marte.

Natura generata il suo cammino simil farebbe sempre a' generanti, se non vincesse il proveder divino”.

Here as before, the line is perfectly Dantean, perfectly secure in point both of substance and of expression. Wanting for nothing, it proceeds with superlative assurance to address a complex issue - the interplay of providence and of personality within the economy of the whole - by way of a series of propositions (socio-political, world-historical and theological) as robust in conception as they are in articulation. But for all that, the Thomist text is once again everywhere to hand as that whereby the hitherto anxious spirit comes home to itself on the plane of understanding:

Sicut supra ostensum est, divina providentia ad omnia singularia se extendit, etiam minima. Quibuscumque igitur sunt aliquae

38 Whereupon he again, "Now say, would it be worse for man on earth if he were not a citizen?" "Yes", I replied, "and here I ask for no proof." "And can that be, unless men below live in diverse ways for diverse duties? Not if your master writes well of this for you." Thus he came deducing as far as here, then he concluded, "Therefore the roots of your works must needs be diverse, so that one is born Solon and another Xerxes, one Melchizedek and another he who flew through the air and lost his son. Circling nature, which is a seal on the mortal wax, performs its art well, but does not distinguish one house from another. Whence it happens that Esau differs in the seed from Jacob, and Quirinus comes from so base a father that he is ascribed to Mars. The begotten nature would always make its course like its begetters, did not divine provision overrule." 
actiones praeter inclinationem speciei, oportet quod per divinam providentiam regulentur in suis actibus praeter directionem quae pertinet ad speciem. Sed in rationali creatura apparent multae actiones ad quas non sufficit inclinatio speciei: cuius signum est quod non similes sunt in omnibus, sed variae in diversis. Oportet igitur quod rationalis creatura dirigatur a Deo ad suos actus non solum secundum speciem, sed etiam secundum individuum.Item. Deus unicuique naturae providet secundum ipsius capacitatem: tales enim singulas creaturas condidit quales aptas esse cognovit ut per suam gubernationem pervenirent ad finem. Sola autem creatura rationalis est capax directionis qua dirigitur ad suos actus non solum secundum speciem, sed etiam secundum individuum: habet enim intellectum et rationem, unde percipere possit quomodo diversimode sit aliquid bonum vel malum secundum quod congruit diversis individuis, temporibus et locis. Sola igitur creatura rationalis dirigitur a Deo ad suos actus non solum secundum speciem, sed etiam secundum individuum.

$(S c G \text { III.cxiii.3-4 })^{39}$

Here again, everything is ready and waiting, the authoritative text reaching out to shape and substantiate the argument: the co-subsistence of specificity and singularity as properties of human being under the aspect of time and space; time and space themselves as the arena of properly human being and becoming; selfhood and the uniqueness thereof as the means of divine purposefulness in the world, of God's carrying out the cosmic plan. Dante, then, could not but have been impressed. Everything is there, everything one could possibly wish for when it comes to human

\footnotetext{
${ }^{39}$ Besides, as we showed above, divine providence extends to all singular things, even to the least. In the case of those beings, then, whose actions take place apart from the inclination appropriate to their species, it is necessary for them to be regulated in their acts by divine providence, over and above the direction which pertains to the species. But many actions are evident, in the case of the rational creature, for which the inclination of the species is not enough. The mark of this is that such actions are not alike in all, but differ in various cases. Therefore, the rational creature must be directed by God in his acts, not only specifically, but also individually. Moreover, God takes care of each nature according to its capacity; indeed, he created singular creatures of such kinds that he knew were suited to achieving the end under his governance. Now, only the rational creature is capable of this direction, whereby his actions are guided, not only specifically, but also individually. For he possesses understanding and reason, and consequently he can grasp in what different ways a thing may be good or bad, depending on its suitability for various individuals, times and places. Therefore, only the rational creature is directed in his acts by God, individually as well as specifically. III. cxxxiv.2: 'Haec autem distributio diversorum officiorum in diversas personas fit divina providentia, secundum quod quidam inclinantur magis ad hoc officium quam ad alia', etc.
} 
and divine intentionality and their coalescence in re. But for all the decisiveness of the archetypal text, it is a question here, less of authority, than of alongsidedness, of how it is that, from out of the garner both of his goodness and of his generosity, one man furnishes another with the means of orderly intellection and thus of orderly actualization. The text, in other words, functions as great texts always do, as that whereby those shaped by them at last stand securely in their own presence, thereafter to rejoice in their indebtedness to everyone and no-one.

But with this we are still in the foothills when it comes to Dante, Aquinas and the relationship between them; for companionship as a cause for celebration in circumstances of sameness, of a common mind among those party to it, comes most completely into its own in circumstances of otherness, of an alternative way of seeing, setting up and resolving the matter to hand. Yet here too, in circumstances of otherness amounting to out and out opposition, Thomas is once again on hand to assist in determining the key emphasis. Take, for example, the case of Conv. III. xv.8-10, a passage designed to stave off a collapse of the whole project in consequence of its now well-nigh impossibly contradictory character. The problem is readily stated, for having in the first treatise of the book committed himself to the possibility of a species of philosophical happiness appropriate to men and women bowed down by civic and domestic care and thus without the leisure for speculation, ${ }^{40}$ and having in the third treatise secured the notion of philosophy as the love of wisdom first and foremost in the mind of God, ${ }^{41}$ Dante is suddenly struck by the implications of the position he has now reached for the viability of his undertaking generally in the Convivio; for if philosophy is first and foremost the love of wisdom in the mind of God, then what use philosophy to the man in the street, to those looking for something more pragmatic, more medium term? Happily, a solution is to hand, Dante's, in this twilight phase of

${ }^{40}$ Conv. I.ix.5 and i.4: 'Ché la bontà de l'animo, la quale questo servigio attende, è in coloro che per malvagia disusanza del mondo hanno lasciata la litteratura a coloro che l'hanno fatta di donna meretrice; e questi nobili sono principi, baroni, cavalieri, e molt'altra nobile gente, non solamente maschi ma femmine, che sono moltie molte in questa lingua, volgari, e non litterati ... Di fuori da l'uomo possono essere similemente due cagioni intese, l'una de le quali è induttrice di necessitade, l'altra di pigrizia. La prima è la cura familiare e civile, la quale convenevolmente a sé tiene de li uomini lo maggior numero, sì che in ozio di speculazione esser non possono'.

${ }^{41}$ Conv. III.xii.12-13: 'Ché se a memoria si reduce ciò che detto è di sopra, filosofia è uno amoroso uso di sapienza, lo quale massimamente è in Dio, però che in lui è somma sapienza e sommo amore e sommo atto; che non può essere altrove, se non in quanto da esso procede. È adunque la divina filosofia de la divina essenza, però che in esso non può essere cosa a la sua essenzia aggiunta; ed è nobilissima, però che nobilissima è la essenzia divina; ed è in lui per modo perfetto e vero, quasi per etterno matrimonio.' 
Convivio III, being a sense of our wanting to know here and now only what it is possible for us to know here and now, anything other than this, any overshooting of the mark, being both misconceived and unnatural:

A ciò si può chiaramente rispondere che lo desiderio naturale in ciascuna cosa è misurato secondo la possibilitade de la cosa desiderante: altrimenti andrebbe in contrario di sé medesimo, che impossibile è; e la Natura l'avrebbe fatto indarno, che è anche impossibile. In contrario andrebbe: ché, desiderando la sua perfezione, desiderrebbe la sua imperfezione; imperò che desiderrebbe sé sempre desiderare e non compiere mai suo desiderio ... Avrebbelo anco la Natura fatto indarno, però che non sarebbe ad alcuno fine ordinato. E però l'umano desiderio è misurato in questa vita a quella scienza che qui avere si può, e quello punto non passa se non per errore, lo quale è di fuori di naturale intenzione ... Onde, con ciò sia cosa che conoscere di Dio e di certe altre cose quello esse sono non sia possibile a la nostra natura, quello da noi naturalmente non è desiderato di sapere. E per questo è la dubitazione soluta. ${ }^{42}$

That he has now contradicted just about everything he has said and is about to say in the Convivio relative to man's desire for God as the beginning and end of all desiring goes without saying, ${ }^{43}$ the

${ }^{42}$ To this the clear answer can be given that the natural desire in everything is in accordance with the capacity of the thing which desires; otherwise the thing would strive in a fashion contrary to its own being, which is impossible; and nature would have made it in vain, which is also impossible. It would strive in a self-contrary fashion, for in desiring its own perfection it would desire its own imperfection, because it would desire always to be desiring and never to satisfy its own desire ... Also, Nature would have made it in vain, because it would not be directed to any end. Human desire, consequently, is measured in this life in accordance with that knowledge which can be gained here, and never passes that point except in error, which is something foreign to the intention of nature ... Since, then, it is impossible for our nature to know of God what he is (the same holds true of certain other things), this is not something which we naturally desire to know. In this way the difficulty is resolved.

${ }^{43}$ Conv. III.ii.7: 'E però che naturalissimo è in Dio volere essere - però che, sì come ne lo allegato libro si legge, "prima cosa è l'essere, e anzi a quello nulla è" -, l'anima umana essere vuole naturalmente con tutto desiderio; e però che 'l suo essere dipende da Dio e per quello si conserva, naturalmente disia e vuole essere a Dio unita per lo suo essere fortificare'; IV.xii.14: 'E la ragione è questa: che lo sommo desiderio di ciascuna cosa, e prima da la natura dato, è lo ritornare a lo suo principio. E però che Dio è principio de le nostre anime e fattore di quelle simili a sé (sì come è scritto: "Facciamo l'uomo ad imagine e similitudine nostra”), essa anima massimamente desidera di tornare a quello.' In the Commedia, Purg. XVII.127-29: 'Ciascun confusamente un bene apprende / nel qual si queti l'animo, e disira; / per che di giugner lui ciascun contende'; Par. II.19-21: 'La concreata e perpetüa sete / del deïforme regno cen portava / veloci quasi come 'l ciel vedete'; VII. 14244: 'ma vostra vita sanza mezzo spira / la somma beninanza, e la innamora / di sé sì che poi 
peremptoriness of it all - the 'A ciò si può chiaramente rispondere' with which the passage begins and the 'E per questo è la dubitazione soluta' with which it ends - testifying to his discomfiture at this point. And that he has also now contradicted everything Aquinas has to say on this matter also goes without saying, Thomas's, albeit with some qualifications along the way, being a sense of man's desire even now, this side of death, to know God as the final cause of his every yearning. But for all that, it is once again Aquinas who, from out of the apologetic abundance of the Contra gentiles, is on hand to furnish, if not the solution exactly, then its essential ingredients, the parts necessary for its hasty assembly:

Vanum enim est quod est ad finem quem non potest consequi. Cum igitur finis hominis sit felicitas, in quam tendit naturale ipsius desiderium, non potest poni felicitas hominis in eo ad quod homo pervenire non potest: alioquin sequeretur quod homo esset in vanum, et naturale eius desiderium esset inane, quod est impossibile.

$(S c G \text { III.xliv.2) })^{44}$

Now Thomas, possessed as he is of a sense of the ultimately uninterrupted teleology of human desiring, has as we have said no interest in the kind of periodization Dante has in mind here, his point in this passage being simply that what we cannot know in this life we shall know in the next:

Adhuc. Impossibile est naturale desiderium esse inane: natura enim nihil facit frustra. Esset autem inane desiderium naturae si nunquam posset impleri. Est igitur implebile desiderium naturale hominis. Non

sempre la disira.' Thomas, $S_{c} G$ III.l.7: 'Nos autem, quantumcumque sciamus Deum esse .... non quiescimus desiderio, sed adhuc desideramus eum per essentiam suam cognoscere'; ST Ia.44.4 ad 3: 'omnia appetunt Deum ut finem, appetendo quodcumque bonum, sive appetitu intelligibili, sive sensibili, sive naturali, qui est sine cognitione, quia nihil habet rationem boni et appetibilis, nisi secundum quod participat Dei similitudinem', etc.

${ }^{44}$ Indeed, a thing is futile which exists for an end which it cannot attain. So, since the end of man is felicity, to which his natural desire tends, it is not possible for the felicity of man to be placed in something than man cannot achieve. Otherwise, it would follow that man is a futile being, and his natural desire would be incapable of fulfilment, which is impossible. For Dante himself on the nature and function of the Contra gentiles as an apologetic undertaking, Conv. IV.xxx.3: 'Dico adunque: Contra-li-erranti mia. Questo Contra-li-erranti è tutto una parte, e è nome d'esta canzone, tolto per essemplo del buono frate Tommaso d'Aquino, che a un suo libro, che fece a confusione di tutti quelli che disviano da nostra Fede, puose nome Contra-li-Gentili.' 
autem in hac vita, ut ostensum est. Oportet igitur quod impleatur post hanc vitam. Est igitur felicitas ultima hominis post hanc vitam.

(ibid. III.xlviii.12) ${ }^{45}$

But that, crystal clear as it is in the text, is not what Dante saw there, or at any rate what he chose to see there; for what Dante saw there was a means of confirming that there must after all be a satisfactory point of arrival on the plane of seeing and understanding bere and now, anything short of this making a mockery of the whole thing. Viewed, in other words, through the eyes of one disposed from deep within himself to rejoice in the realizability of the human project under certain at least of its aspects in the historical order, the Contra gentiles, with its talk of the futility of it all short of a positive outcome (the 'alioquin sequeretur quod homo esset in vanum' of the III.xliv.2 passage), was just what he needed, a means of saving both himself and his current project.

As a further example of Thomas's coming to Dante's aid in the moment of his setting off in a fresh direction, we may take the question of secondary causality, the role of the separate substances within the general scheme of things. Dante's position in this matter - not, in fact, a comfortable one involves a combination of the creationist proper and of the processionist; for though pure form, pure matter and their amalgamation in the heavenly bodies (to which for the sake of completeness we should add the rational soul in man) are understood by him to be the immediate product of divine creativity, ${ }^{46}$ form, even in its first instantiation as the intelligible and operative principle of a thing, is referred to the separate substances by which those same bodies appear to be animated. ${ }^{47}$ Everything that $i$, in

\footnotetext{
${ }^{45}$ Again, it is impossible for natural desire to be unfulfilled, since "nature does nothing in vain" [De caelo ii.11; 291b13]. Now, natural desire would be in vain if it could never be fulfilled. Therefore, man's natural desire is capable of fulfilment, but not in this life, as we have shown. So it must be fulfilled after this life. Therefore, man's ultimate felicity comes after this life.
}

${ }^{46}$ Par. XXIX.13-36, with Purg. XXV.67-75 and Conv. IV.xxi.4-5 on God's in-breathing of the rational soul into the vegetative and sensitive soul generated ex materia. S. Bemrose, "Come d'animal divegna fante": the Animation of the Human Embryo in Dante', in The Human Embryo. Aristotle and the Arabic and European Traditions, ed. G. R. Dunstan (Exeter: Exeter University Press, 1990), pp. 123-35.

${ }^{47}$ Par. II.139-41: 'Virtù diversa fa diversa lega / col prezïoso corpo ch'ella avviva, / nel qual, sì come vita in voi, si lega.' D. O'Keeffe, 'Dante's Theory of Creation', Revue néoscolastique, 26 (1924), 45-64; B. Nardi, Nel mondo di Dante (note 3 above), pp. 307-13; idem, 'Dante e Pietro d'Abano', in Saggidifilosofia dantesca (note 3 above), pp. 40-62 (especially pp. 42-45); A. Mellone, O.F.M., La dottrina di Dante Alighieri sulla prima creazione, 'Emanatismo neoplatonico di Dante per le citazioni del Liber de Causis?', and 'Il concorso delle creature nella produzione delle cose secondo Dante' (note 21 above); idem, ad voc. 'Creazione', in the Enciclopedia dantesca, 6 vols (Rome: Istituto dell'Enciclopedia Italiana, 1970-78), 
other words, in the sublunary world (the rational soul of man apart) receives its substantial form - that by virtue of which it is what it is and does what it does - from the Intelligences, Dante's being in this sense a firm commitment in the areas both of creation theology and of general cosmology to the role of intermediate causality in the universe:

Tu dici: "Io veggio l'acqua, io veggio il foco,

l'aere e la terra e tutte lor misture

venire a corruzione, e durar poco;

e queste cose pur furon creature;

per che, se ciò ch'è detto è stato vero,

esser dovrien da corruzion sicure".

$\mathrm{Li}$ angeli, frate, e 'l paese sincero

nel qual tu se', dir si posson creati,

sì come sono, in loro essere intero;

ma li alimenti che tu hai nomati

e quelle cose che di lor si fanno

da creata virtù sono informati.

Creata fu la materia ch'elli hanno;

creata fu la virtù informante

in queste stelle che 'ntorno a lor vanno.

L'anima d'ogne bruto e de le piante

di complession potenzïata tira

lo raggio e 'l moto de le luci sante;

ma vostra vita sanza mezzo spira

la somma beninanza, e la innamora

di sé sì che poi sempre la disira.

(Par. VII.124-44) $)^{48}$

vol. 2, pp. 251-53; J. A. Mazzeo, 'The Analogy of Creation', Speculum 32 (1957), 706 21; E. Moore, 'Dante's Theory of Creation', in Studies in Dante, Fourth Series, edited and with new introductory matter by C. Hardie (Oxford: Clarendon Press, 1968; originally 1917), pp. 134-65; S. Bemrose, Dante's Angelic Intelligences: Their Importance in the Cosmos and in Pre-Christian Religion (note 21 above), pp. 90-113. On the animation of the stars, Par. II.139-41: 'Virtù diversa fa diversa lega / col prezïoso corpo ch'ella avviva, / nel qual, sì come vita in voi, si lega.' Thomas (reporting Aristotle) has: 'Est igitur caelum compositum, secundum opinionem Aristotelis, ex anima intellectuali et corpore. Et hoc significat in II de anima [ii.3; 414b19], ubi dicit quod "quibusdam inest intellectivum et intellectus: ut hominibus, et si aliquid huiusmodi est alterum, aut honorabilius", scilicet caelum' (ScG II.lxx.4, though cf. 8: 'Hoc autem quod dictum est de animatione caeli, non diximus quasi asserendo secundum fidei doctrinam, ad quam nihil pertinet sive sic sive aliter dicatur. Unde Augustinus, in libro Enchiridion [I.lviii, ult.], dicit: "nec illud quidem certum habeo, utrum ad eandem societatem, scilicet Angelorum, pertineant sol et luna et cuncta sidera: quamvis nonnullis lucida esse corpora, non cum sensu vel intelligentia, videantur"').

48 You say, "I see water, I see fire and air and earth, and all their mixtures come to corruption and endure but little, and yet these things were created things; so that, if 
Now here, as Kenelm Foster was quick to affirm, ${ }^{49}$ Thomas is unambiguous, his, both in and beyond the Contra gentiles, being an equally firm sense of form in its preliminary manifestation as the immediate product of divine creativity, of the original and abiding let it be whereby something is brought forth from nothing, to suppose otherwise being to countenance the notion of pure subsistent matter:

Prima inductio formarum in materia non potest esse ab aliquo agente per motum tantum: omnis enim motus ad formam est ex forma determinata in formam determinatam; quia materia non potest esse absque omni forma, et sic praesupponitur aliqua forma in materia. Sed omne agens ad formam solam materialem oportet quod sit agens per motum: cum enim formae materiales non sint per se subsistentes, sed earum esse sit inesse materiae, non possunt produci in esse nisi vel per creationem totius compositi, vel per transmutationem materiae ad talem vel talem formam. Impossibile est igitur quod prima inductio formarum in materia sit ab aliquo creante formam tantum: sed ab eo qui est creator totius compositi.

$(S c G \text { II.xliii.5 })^{50}$

what I have said to you be true, they ought to be secure against corruption". The angels, brother, and the pure country in which you are, may be said to be created even as they are, in their entire being; but the elements which you have named, and all things that are compounded of them, are informed by created power. Created was the matter that is in them, created was the informing virtue in these stars that wheel about them. The soul of every beast and of the plants is drawn from a compound potentiated by the shining and motion of the holy lights; but your life the supreme beneficence breathes forth without intermediary, and so enamours it of itself that it desires it ever after.

${ }^{49}$ Dante e San Tommaso (note 16 above), pp. 12-16.

${ }^{50}$ The first induction of forms into matter cannot have originated from an agent acting by means of movement only. All motion directed to a form is from a determinate form toward a determinate form, for matter cannot exist in the absence of all form; the existence of some form in matter is presupposed. But every agent whose action is directed only toward material forms is necessarily an agent that acts by means of motion. For, since material forms are not self-subsistent, and since, in their case, to be is to be in matter, there are but two possible ways in which they can be brought into being: either by the creation of the whole composite, or by the transmutation of matter to this or that form. The first induction of forms into matter, therefore, cannot possibly be from an agent that creates the form alone; rather, this is the work of him who is the creator of the whole composite. Similarly, ST Ia.65.4 resp.: 'opinio fuit quorundam quod omnes formae corporales deriventur a substantiis spiritualibus quas Angelos dicimus. Et hoc quidem dupliciter aliqui posuerunt. Plato enim posuit formas quae sunt in materia corporali, derivari et formari a formis sine materia subsistentibus, per modum participationis cuiusdam. Ponebat enim hominem quendam immaterialiter subsistentem, et similiter equum, et sic de aliis, ex quibus constituuntur haec singularia sensibilia, secundum quod in materia corporali remanet quaedam impressio ab illis formis separatis, per modum assimilationis cuiusdam, quam participationem vocabat. Et secundum ordinem 
The position, then, is clear: no secondary causality at the point of inception. Subsequently, yes, for secondary causality is everywhere present to being as part of its fundamental mechanism, but at the point of inception, no. ${ }^{51}$ But that is not what Dante found in the text; for, sensitive as

formarum ponebant Platonici ordinem substantiarum separatarum, puta quod una substantia separata est quae est equus, quae est causa omnium equorum; supra quam est quaedam vita separata, quam dicebant per se vitam et causam omnis vitae; et ulterius quandam quam nominabant ipsum esse, et causam omnis esse. Avicenna vero et quidam alii non posuerunt formas rerum corporalium in materia per se subsistere, sed solum in intellectu. A formis ergo in intellectu creaturarum spiritualium existentibus (quas quidem ipsi intelligentias, nos autem Angelos dicimus), dicebant procedere omnes formas quae sunt in materia corporali, sicut a formis quae sunt in mente artificis, procedunt formae artificiatorum ... Omnes autem hae opiniones ex una radice processisse videntur. Quaerebant enim causam formarum, ac si ipsae formae fierent secundum seipsas. Sed sicut probat Aristoteles in VII Metaphys., id quod proprie fit, est compositum, formae autem corruptibilium rerum habent ut aliquando sint, aliquando non sint, absque hoc quod ipsae generentur aut corrumpantur, sed compositis generatis aut corruptis, quia etiam formae non habent esse, sed composita habent esse per eas, sic enim alicui competit fieri, sicut et esse. Et ideo, cum simile fiat a suo simili, non est quaerenda causa formarum corporalium aliqua forma immaterialis; sed aliquod compositum, secundum quod hic ignis generatur ab hoc igne. Sic igitur formae corporales causantur, non quasi influxae ab aliqua immateriali forma, sed quasi materia reducta de potentia in actum ab aliquo agente composito. Sed quia agens compositum, quod est corpus, movetur a substantia spirituali creata, ut Augustinus dicit III de Trin.; sequitur ulterius quod etiam formae corporales a substantiis spiritualibus deriventur, non tanquam influentibus formas, sed tanquam moventibus ad formas. Ulterius autem reducuntur in Deum, sicut in primam causam, etiam species angelici intellectus, quae sunt quaedam seminales rationes corporalium formarum. In prima autem corporalis creaturae productione non consideratur aliqua transmutatio de potentia in actum. Et ideo formae corporales quas in prima productione corpora habuerunt, sunt immediate a Deo productae, cui soli ad nutum obedit materia, tanquam propriae causae.'

${ }^{51} \operatorname{Sc} G$ III.ciii.3 (over against Avicenna's sense of material agency as merely dispositive with respect to separate agency): 'Haec autem positio satis consona est aliis suis positionibus. Ponit enim [i.e. Avicenna] quod omnes formae substantiales effluunt in haec inferiora a substantia separata; et quod corporalia agentia non sunt nisi disponentia materiam ad suscipiendam impressionem agentis separati. Quod quidem non est verum secundum Aristotelis doctrinam, qui probat in VII Metaphys., quod formae quae sunt in materia, non sunt a formis separatis, sed a formis quae sunt in materia; sic enim invenietur similitudo inter faciens et factum'; ST Ia 110.2 resp.: 'Respondeo dicendum quod Platonici posuerunt formas quae sunt in materia, causari ex immaterialibus formis, quia formas materiales ponebant esse participationes quasdam immaterialium formarum. Et hos, quantum ad aliquid, secutus est Avicenna, qui posuit omnes formas quae sunt in materia, procedere a conceptione intelligentiae, et quod agentia corporalia sunt solum disponentia ad formas. Qui in hoc videntur fuisse decepti, quia existimaverunt formam quasi aliquid per se factum, ut sic ab aliquo formali principio procederet. Sed sicut philosophus probat in VII Metaphys., hoc quod proprie fit, est compositum, hoc enim proprie est quasi subsistens. Forma autem non dicitur ens quasi ipsa sit, sed sicut quo aliquid est, et sic per consequens nec forma proprie fit; eius enim est fieri, cuius est esse, cum fieri nihil aliud sit quam via in esse. Manifestum est autem quod factum est simile facienti, quia omne agens 
he must have been to Thomas's general position, he nonetheless discovered as he read on into Book III of the Contra gentiles what seemed to him to be an exemplary account, if not of the generation, then of the transmission of form, even in its primary instantiation, by the separate substances. In this, he was mistaken, for Thomas, again, will have none of it. But read in a certain way and with a dash of enthusiasm, the text does indeed hold out possibilities, namely a sense $(a)$ of form as pre-existent in the intellect of 'some substance or substances' ('in intellectu alicuius substantiae, vel aliquarum'); (b) of form in matter as proceeding from form without matter ('formae quae sunt in materia, venerunt a formis quae sunt sine materia); (c) of form generally as a product of movement in the heavens ('et causantes formas inferiores per motum caeli'); $(\partial)$ of the Intelligences as directive ('sicut directa in finem a substantia intelligente'); and (e) of form as proceeding from natural - in the sense of 'natured' or created - bodies ('ex moventibus naturalibus'). Thus everything once again is to hand, Thomas, never less than careful in the area of secondary causality, appearing to authorize the alternative emphasis:

$\mathrm{Si}$ autem corpus caeleste a substantia intellectuali movetur, ut ostensum est; motus autem corporis caelestis ordinatur ad generationem in inferioribus: necesse est quod generationes et motus istorum inferiorum procedant ex intentione substantiae intelligentis. In idem enim fertur intentio principalis agentis, et instrumenti. Caelum autem est causa inferiorum motuum secundum suum motum, quo movetur a substantia intellectuali. Sequitur ergo quod sit sicut instrumentum intellectualis substantiae. Sunt igitur formae et motus inferiorum corporum a substantia intellectuali causatae et intentae sicut a principali agente, a corpore vero caelesti sicut ab instrumento.

Oportet autem quod species eorum quae causantur et intenduntur ab intellectuali agente, praeexistant in intellectu ipsius: sicut formae artificiatorum praeexistunt in intellectu artificis, et ex eis deriventur in effectus. Omnes igitur formae quae sunt in istis inferioribus, et omnes motus, derivantur a formis intellectualibus quae sunt in intellectu alicuius substantiae, vel aliquarum. Et propter hoc dicit Boetius, in libro de Trin., quod "formae quae sunt in materia, venerunt a formis quae sunt sine materia". Et quantum ad hoc verificatur dictum Platonis, quod formae separatae sunt principia formarum quae sunt in materia: licet Plato posuerit eas per se subsistentes, et

agit sibi simile. Et ideo id quod facit res naturales, habet similitudinem cum composito, vel quia est compositum, sicut ignis generat ignem; vel quia totum compositum, et quantum ad materiam et quantum ad formam, est in virtute ipsius; quod est proprium Dei. Sic igitur omnis informatio materiae vel est a Deo immediate, vel ab aliquo agente corporali; non autem immediate ab Angelo', etc. 
causantes immediate formas sensibilium; nos vero ponamus eas in intellectu existentes, et causantes formas inferiores per motum caeli.

Quia vero omne quod movetur ab aliquo per se, non secundum accidens, dirigitur ab eo in finem sui motus; corpus autem caeleste movetur a substantia intellectuali; corpus autem caeleste causat per sui motum omnes motus in istis inferioribus: necessarium est quod corpus caeleste dirigatur in finem sui motus per substantiam intellectualem, et per consequens omnia inferiora corpora in proprios fines.

Sic igitur non est difficile videre qualiter naturalia corpora cognitione carentia moveantur et agant propter finem. Tendunt enim in finem sicut directa in finem a substantia intelligente, per modum quo sagitta tendit ad signum directa a sagittante. Sicut enim sagitta consequitur inclinationem ad finem determinatum ex impulsione sagittantis, ita corpora naturalia consequuntur inclinationem in fines naturales ex moventibus naturalibus, ex quibus sortiuntur suas formas et virtutes et motus.

$(S c G \text { III.xxiv.1-4) })^{52}$

${ }^{52}$ Now, if a celestial body is moved by intellectual substance, as we have shown, and if the motion of a celestial body is ordered to generation in the realm of things here below, it must be that the processes of generation and the motions of these lower things start from the intention of an intelligent substance. For the intention of the principal agent and that of the instrument are directed toward the same thing. Now, the heaven is the cause of the movements of inferior bodies, by virtue of its own motion in which it is moved by an intellectual substance. It follows, then, that the heavenly body is like an instrument for intellectual substance. Therefore, the forms and movements of lower bodies are caused by intellectual substance which intends them as a principal agent, while the celestial body is like an instrument.

It must be, then, that the species of things caused and intended by the intellectual agent exist beforehand in his intellect, as the forms of artifacts pre-exist in the intellect of the artist and are projected from there into their products. So, all the forms that are in these lower substances, and all their motions, are derived from the intellectual forms which are in the intellect of some substance or substances. Consequently, Boethius says in his book, The Trinity, that "forms which are in matter have come from forms which are without matter". And on this point, Plato's statement is verified, that forms separated from matter are the principles of forms that are in it. Although Plato claimed that they subsist in themselves and immediately cause the forms of sensible things, we assert that they exist in an intellect and cause lower forms through the motion of the heavens.

Since everything that is moved directly and not merely accidentally by another being is directed by that being to the end of its motion, and since the celestial body is moved by an intellectual substance, and, moreover, the celestial body causes, through its own motion, all the motions in these lower things, the celestial body must be directed to the end of its motion by an intellectual substance, and so must all lower bodies be directed to their own ends.

So, then, it is not difficult to see how natural bodies, devoid of knowledge, are moved and perform actions for an end. They tend to the end as things directed to that end by 
Here too, then, the text functions, not as a source, but as a stimulus, as apt from out of its particular kind of spaciousness to quicken the independent initiative.

As a final instance of this same process, of the tendency of the Thomist text to function in Dante as a principle of emancipation, we may take the case of his embryology, his account of the genesis of the rational soul as the formal principle of specifically human being and doing, ${ }^{53}$ for here too Dante is both with Thomas and against him. He is with him in so far as for Thomas too the rational soul in man is understood to come from beyond, to be infused into the psychosomatic totality ab extra. He is against him in so far as his - Dante's - is a transformational or evolutionary account of the soul in its vegetative and sensitive aspects, an account envisaging a series of mutations at the level of form until at last the soul generated ex materia is ready for the in-breathing of its rational component by God. The key passage here, Purg. XXV.52-60, reads as follows:

Anima fatta la virtute attiva qual d'una pianta, in tanto differente, che questa è in via e quella è già a riva,

tanto ovra poi, che già si move e sente, come spungo marino; e indi imprende ad organar le posse ond' è semente.

Or si spiega, figliuolo, or si distende la virtù ch'è dal cor del generante, dove natura a tutte membra intende..$^{54}$

an intellectual substance, in the way that an arrow tends toward the target when it has been aimed by the archer. Just as the arrow attains its inclination to a definite end from the archer's act of shooting it, so do natural bodies attain their inclination to natural ends, from natural movers; from which movers they also receive their forms, powers, and motions.

${ }_{53}$ B. Nardi, Sigieri di Brabante nella Divina Commedia e le fonti della filosofia di Dante (Spianate (Pescia): Presso l'Autore, 1912; four articles published originally in the Rivista difilosofia neo-scolastica in 1911 and 1912), pp. 43-52; idem, 'Intorno al tomismo di Dante e alla quistione di Sigieri' (note 3 above); idem, 'Noterelle polemiche di filosofia dantesca', Nuovo giornale Jantesco I (1917), 123-29; idem, 'Sull'origine dell'anima umana', in Dante e la cultura medievale (Bari: Laterza, 1949), pp. 260-83; idem, 'La formazione dell'anima umana secondo Dante', in Studi di filosofia medievale (Rome: Edizioni di Storia e di Letteratura, 1960, with an anastatic reprint in 1979), pp. 9-68 (with 'L'anima umana secondo Sigieri' at pp. 151-161); idem, 'll tomismo di Dante e il p. Busnelli, S. J.', in Saggi difilosofia dantesca (note 3 above), pp. 341-80 (especially pp. 359 ff.); S. Bemrose, "'Come d'animal divegna fante": the Animation of the Human Embryo in Dante' (note 46 above).

${ }^{54}$ The active virtue having become a soul, like that of a plant (but different in so far as this is on the way, and that has already arrived), so works then that now it moves and feels, like a sea-fungus; then it proceeds to develop organs for the power of which it is the germ. Now, my son, expands, now distends, the virtue which proceeds from the 
For Thomas, this is out of the question, for form, he believes, is impatient of gradual implementation or of affirmation by degrees, a position secure both in the Contra gentiles and in the Summa theologiae. ${ }^{55}$ Rather, the question stands for him to be set up substitutionally rather than transformationally, the sensitive and the rational each alike taking the place of its predecessor as distinct from constituting the term of its development. Here too, however, it is Thomas who, for all his rejection of anything resembling a gradualistic account of the psychogenetic issue in man, provides Dante with what he needs for his own solution, the passage from Canto XXV cited a moment ago not only reflecting but invoking Thomist ways of thinking and speaking:

heart of the begetter, where nature makes provision for all the members. With a slight redistribution of emphases, Conv. IV.xxi.4-5: 'E però dico che quando l'umano seme cade nel suo recettaculo, cioè ne la matrice, esso porta seco la vertù de l'anima generativa e la vertù del cielo e la vertù de li elementi legati, cioè la complessione; e matura e dispone la materia a la vertù formativa, la quale diede l'anima del generante; e la vertù formativa prepara li organi a la vertù celestiale, che produce de la potenza del seme l'anima in vita. La quale, incontanente produtta, riceve da la vertù del motore del cielo lo intelletto possibile; lo quale potenzialmente in sé adduce tutte le forme universali, secondo che sono nel suo produttore, e tanto meno quanto più dilungato da la prima Intelligenza è.'

55 ScG II.lxxxix.6: 'Secundum enim hanc positionem, sequeretur quod aliqua virtus eadem numero nunc esset anima vegetabilis tantum, et postmodum anima sensitiva: et sic ipsa forma substantialis continue magis ac magis perficeretur. Et ulterius sequeretur quod non simul, sed successive educeretur forma substantialis de potentia in actum. Et ulterius quod generatio esset motus continuus, sicut et alteratio. Quae omnia sunt impossibilia in natura'; ST Ia.118.2 ad 2: 'Dicunt ergo quidam quod supra animam vegetabilem quae primo inerat, supervenit alia anima, quae est sensitiva; et supra illam iterum alia, quae est intellectiva. Et sic sunt in homine tres animae, quarum una est in potentia ad aliam. Quod supra improbatum est. Et ideo alii dicunt quod illa eadem anima quae primo fuit vegetativa tantum, postmodum, per actionem virtutis quae est in semine, perducitur ad hoc quod fiat etiam sensitiva; et tandem perducitur ad hoc ut ipsa eadem fiat intellectiva, non quidem per virtutem activam seminis, sed per virtutem superioris agentis, scilicet Dei deforis illustrantis. Et propter hoc dicit philosophus quod intellectus venit ab extrinseco. Sed hoc stare non potest. Primo quidem, quia nulla forma substantialis recipit magis et minus; sed superadditio maioris perfectionis facit aliam speciem, sicut additio unitatis facit aliam speciem in numeris. Non est autem possibile ut una et eadem forma numero sit diversarum specierum. Secundo, quia sequeretur quod generatio animalis esset motus continuus, paulatim procedens de imperfecto ad perfectum; sicut accidit in alteratione. Tertio, quia sequeretur quod generatio hominis aut animalis non sit generatio simpliciter, quia subiectum eius esset ens actu. Si enim a principio in materia prolis est anima vegetabilis, et postmodum usque ad perfectum paulatim perducitur; erit semper additio perfectionis sequentis sine corruptione perfectionis praecedentis. Quod est contra rationem generationis simpliciter. Quarto, quia aut id quod causatur ex actione Dei, est aliquid subsistens, et ita oportet quod sit aliud per essentiam a forma praeexistente, quae non erat subsistens; et sic redibit opinio ponentium plures animas in corpore. Aut non est aliquid subsistens, sed quaedam perfectio animae praeexistentis, et sic ex necessitate sequitur quod anima intellectiva corrumpatur, corrupto corpore; quod est impossibile'; II Sent. 18.2.1 resp., etc. 
etsi a principio decisionis in semine non sit anima actu, sed virtute, propter deficientiam organorum; tamen ipsammet virtutem seminis, quod est corpus organizabile, etsi non organizatum, esse proportionaliter semini animam in potentia, sed non actu; et quia vita plantae pauciora requirit organa quam vita animalis, primo semine sufficienter ad vitam plantae organizato, ipsam praedictam virtutem fieri animam vegetabilem; deinde, organis magis perfectis et multiplicatis, eandem perduci ut sit anima sensitiva; ulterius autem, forma organorum perfecta, eandem animam fieri rationalem, non quidem per actionem virtutis seminis, sed ex influxu exterioris agentis, propter quod suspicantur Aristotelem dixisse intellectum ab extrinseco esse, in libro de generatione animalium.

$(S c G \text { II.lxxxix.6 })^{56}$

Here too, therefore, everything is ready and waiting: Thomas's 'vita plantae pauciora' for Dante's 'qual d'una pianta'; Thomas's 'in semine non sit anima actu ... semini animam in potentia' for Dante's 'le posse ond' è semente'; Thomas's 'organa quam vita animalis ... ad vitam plantae organizato ... forma organorum perfecta' for Dante's 'ad organar le posse'. True, there are other possibilities, Dante's proposal of this matter in terms of a series of inchoative instants - of the vegetative as embryonic in respect of the sensitive and of the sensitive as embryonic in respect of the rational - looking very much like Albert's in the De natura et origine animae (I.v):

${ }^{56}$ From the moment of severance the soul is not present in the semen actually but virtually, because of the lack of organs; and yet this very power of the semen - itself a body potentially endowed with organs though actually without them - is, proportionately to the semen, a potential but not an actual soul. Moreover, since plant life requires fewer organs than animal life, from the moment that the organic development of the semen suffices for plant life, the aforesaid seminal power becomes a vegetative soul; and later, the organs having been perfected and multiplied still more, the same power is raised to the level of a sensitive soul; and finally, with the perfecting of the organs' form, the same soul becomes rational, not, indeed, by the action of that seminal power, but through the influx of an external agent. And for this reason the proponents of the theory suppose Aristotle to have said in the $D e$ generatione animalium [ii.3; 736b28] that "the intellect is from without". Cf. III.xxii.7: "In actibus autem formarum gradus quidam inveniuntur. Nam materia prima est in potentia primo ad formam elementi. Sub forma vero elementi existens est in potentia ad formam mixti: propter quod elementa sunt materia mixti. Sub forma autem mixti considerata, est in potentia ad animam vegetabilem: nam talis corporis anima actus est. Itemque anima vegetabilis est potentia ad sensitivam; sensitiva vero ad intellectivam. Quod processus generationis ostendit: primo enim in generatione est fetus vivens vita plantae, postmodum vero vita animalis, demum vero vita hominis. Post hanc autem formam non invenitur in generabilibus et corruptibilibus posterior forma et dignior. Ultimus igitur finis generationis totius est anima humana, et in hanc tendit materia sicut in ultimam formam. Sunt ergo elementa propter corpora mixta; haec vero propter viventia; in quibus plantae sunt propter animalia; animalia vero propter hominem. Homo igitur est finis totius generationis.' 
Oportet autem scire, quod, sicut in aliis, ita etiam in homine inchoatio vegetativi est in materia et in esse primo substantiae animandae, et inchoatio sensibilis est in vegetativo, et inchoatio rationalis in sensitivo est ... Ostensum est etiam per ante dicta, quod substantia illa quae est anima hominis partim est ab intrinseco et partim $a b$ extrinseco ingrediens: quia licet vegetativum et sensitivum in homine de materia educantur mediante virtute formativa, quae est in gutta matris et patris, tamen haec formativa non educeret eas hoc modo prout sunt potentiae rationalis et intellectualis formae et substantiae, nisi secundum quod ipsa formativa movetur informata $\mathrm{ab}$ intellectu universaliter movente in opere generationis; et ideo complementum ultimum quod est intellectualis formae et substantiae non per instrumentum neque ex materia, sed per lucem suam influit intellectus primae causae purus et immixtus. ${ }^{57}$

But for all its status as exemplary in respect of the transformational as opposed to the substitutional, there can be no privileging of the $D e$

${ }^{57}$ What we have to understand is that, in man as in other things, the beginning of the vegetative is in matter itself, in the original being of the substance to be quickened, and the beginning of the sensitive in the vegetative, and the beginning of the rational in the sensitive ... It has already been demonstrated in the aforesaid that the substance that is the human soul comes partly from within and partly from beyond; for although the vegetative and the sensitive are brought forth from matter by way of the formative virtue, which is in the fluids of the mother and the father, nonetheless this formative virtue would not bring them forth such that they were powers of the rational soul and of an intellectual form and substance were not that same formative virtue itself moved and informed by the universal intellect at work in the process of generation. Therefore, the point of arrival, which is an intellectual form and substance, is accomplished, not instrumentally or by way of matter, but through an influx of the pure and uncontaminated light of the divine mind as its first cause (text in B. Nardi, 'Alcuni luoghi di Alberto Magno e di Dante', in Saggi di filosofia Jantesca (note 3 above), pp. 63-72 at p. 71). Thomas, preparatory to rejecting this position, summarises thus in the De pot. at 3.9 ad 9: 'Unde alii dicunt, quod anima vegetabilis est in potentia ad animam sensibilem et sensibilis est actus eius; unde anima vegetabilis quae primo est in semine, per actionem naturae perducitur ad complementum animae sensibilis; et ulterius anima rationalis est actus et complementum animae sensibilis; unde anima sensibilis perducitur ad suum complementum, scilicet ad animam rationalem, non per actionem generantis sed per actum creantis; et sic dicunt quod ipsa rationalis anima in homine partim est ab intrinseco, scilicet quantum ad naturam intellectualem; et partim ab extrinseco, quantum ad naturam vegetabilem et sensibilem. Sed hoc nullo modo potest stare: quia vel hoc ita intelligitur quod natura intellectualis sit alia anima a vegetabili et sensibili, et sic redit in idem cum secunda opinione: vel intelligitur ita quod ex istis tribus naturis constituatur substantia animae in qua natura intellectualis erit ut formale, et natura sensibilis et vegetabilis erit ut materiale. Ex quo sequitur quod cum natura sensibilis et vegetabilis sint corruptibiles, utpote de materia eductae, substantia animae humanae non possit esse perpetua. Sequitur idem etiam inconveniens quod inductum est contra primam, scilicet quod forma substantialis successive educatur in actum.' 
natura et origine animae over the Contra gentiles as the key text here, the difficulty of the Albertan line in both its lexical and syntactical choices (inchoatio vegetativi ... substantiae animandae ... nisi secundum quod ipsa formativa movetur informata $\mathrm{ab}$ intellectu movente ... complementum ultimum') tending to confirm over against the conceptual and expressive congeniality of the Thomist text the remoteness of the former as Dante's 'control', as his vademecum in the area of psychogenesis. On the contrary, his chosen companion, guide and counsellor remains the Contra gentiles, a text which, in its commitment to the sorting and sifting of competing emphases (for that is the business of apologetics), provides him with just what he needs in his determination to look the other way.

4. Dante's celebration of Aquinas as spokesman for the sage spirits in paradise testifies to what he saw and most appreciated in him, namely, his poise as a philosophical spirit, his mastery of the Aristotelian text, and, as informing the entire undertaking, the piety of it all, the transparency of the Thomist utterance to something other and greater than itself. But for all his admiration and affection for Thomas as master of the syllogistic statement, as incomparable in his sense of what Aristotle was and of why Aristotle matters, and as secure in his understanding of what it is to live humbly in Christ, Dante's was an alternative sense of the theological project, of what theology is and of how it stands to be done; for the theological project in Dante stands to be proposed by way, not so much of the propositional as of the predicamental, of the crisis of existence into which the contents of propositional awareness enter as a principle of resurrection, as that whereby the soul lays hold at last of its proper inheritance. Now this, as a way of describing the situation in Dante, needs careful statement, since for all his starting out from the crisis of existence as the across which of theological awareness and as the whereabouts of its verification, there can be no referral of the essential to the existential component of his spirituality as to its point of departure, for it is the essential component of that spirituality which, as the prius of everything coming next by way both of the substance and of the phenomenology of the moral and religious life (both of the what and of the bow of that life), determines the shape and substance of the existential crisis in the first place. On the one hand, then, we have the dogmatic moment of the text, the moment which, turning as it does upon creation as a matter of the love-overflowing of the Godhead, upon the catastrophe of Eden as a matter of perverse willing, and upon the Christ event as a matter of moral and ontological re-potentiation, constitutes, not only the prius, but the encompassing of the crisis engendered by the forces of reckless selfhood, by the standing of self over against self in 
the forum of conscience; so, for example, on the first of these things, on creation as but the love-extrinsication of the Godhead and on this as the ground in man of the immortality, of the freedom and of the Godlikeness properly his from the outset, these lines (13-18 and 64-75) from Cantos XXIX and VII of the Paradiso:

Non per aver a sé di bene acquisto,

ch'esser non può, ma perché suo splendore potesse, risplendendo, dir "Subsisto", in sua etternità di tempo fore, fuor d'ogne altro comprender, come i piacque, s'aperse in nuovi amor l'etterno amore. $\cdots$

La divina bontà, che da sé sperne ogne livore, ardendo in sé, sfavilla sì che dispiega le bellezze etterne.

Ciò che da lei sanza mezzo distilla non ha poi fine, perché non si move la sua imprenta quand' ella sigilla.

Ciò che da essa sanza mezzo piove libero è tutto, perché non soggiace a la virtute de le cose nove.

Più l'è conforme, e però più le piace; ché l'ardor santo ch'ogne cosa raggia, ne la più somigliante è più vivace. ${ }^{58}$

while on the second of them, on the impudence of Eden as man's response to the love-overflowing of the Godhead thus understood, these (lines 22-30 and 115-17) from Canto XXIX of the Purgatorio and Canto XXVI of the Paradiso:

E una melodia dolce correva

per l'aere luminoso; onde buon zelo

mi fé riprender l'ardimento d'Eva,

che là dove ubidia la terra e 'l cielo,

${ }^{58}$ Not for gain of good unto himself, which cannot be, but that his splendour might, in resplendence, say "Subsisto" - in his eternity beyond time, beyond every other bound, as it pleased him, the eternal love opened in new loves ... The divine goodness, which spurns all envy from itself, burning within itself so sparkles that it displays the eternal beauties. That which derives immediately from it therefore has no end, because when it seals, its imprint may never be removed. That which rains down from it immediately is wholly free, because it is not subject to the power of the new things. It is the most conformed to it and therefore pleases it the most; for the holy ardour, which irradiates everything is most living in what is most like itself. 
femmina, sola e pur testé formata, non sofferse di star sotto alcun velo; sotto 'l qual se divota fosse stata, avrei quelle ineffabili delizie sentite prima e più lunga fỉata. $\cdots$

Or, figluol mio, non il gustar del legno

fu per sé la cagion di tanto essilio, ma solamente il trapassar del segno. ${ }^{59}$

and on the third of them, on the Father's work in the Son as a matter of God's renewing man in his power to moral and eschatological selfdetermination, these (lines 106-20) from, again, Canto VII of the Paradiso:

\author{
Ma perché l'ovra tanto è più gradita \\ da l'operante, quanto più appresenta \\ de la bontà del core ond' ell' è uscita, \\ la divina bontà che 'l mondo imprenta,
}

\begin{abstract}
${ }^{59}$ And a sweet melody ran through the luminous air; wherefore good zeal made me reprove Eve's daring, that, there where earth and heaven were obedient, a woman, alone and but then formed, did not bear to remain under any veil, under which, if she had been devout, I should have tasted those ineffable delights before, and for a longer time ... Now know, my son, that the tasting of the tree was not in itself the cause of so long an exile, but solely the overpassing of the bound. Cf. Par. XXXII. 121-23: 'colui che da sinistra le s'aggiusta / è il padre per lo cui ardito gusto / l'umana specie tanto amaro gusta.' N. Borsellino, 'Notizie sull'Eden (Paradiso XXVI)', Lettere Italiane 41 (1989), 3, 321-33 (and in Sipario dantesco. Sei scenari della Commedia (Rome: Salerno, 1991), pp. 88-101); L. Cardellino, 'Struttura del poema e senso del viaggio. Eden: peccato originale e umiltà, in Autocritica infernale (Milan: Jaca Book,1992), pp. 25-51; C. A. Mangieri, 'L'Eden dantesco: allegorismo e significazione', Italian Quarterly 41, 161-62 (2004), 5-53; W. W. Marshall, 'Dante and the Doctrine of Original Sin. A Theological Gloss on Purgatorio XVI, 80-105 and Paradiso XXVII, 121-41', Dante. Rivista internazionale di studi su Dante Alighieri 3 (2006), 21-40. Also, B. Nardi, 'Il concetto dell'impero nello svolgimento del pensiero dantesco', in Saggi di filosofia dantesca (note 3 above), pp. 215-75 (especially pp. 215-28). More generally, H. Rondet, Original Sin: the Patristic and Theological Background, trans. C. Finegan (Shannon, Eire: Ecclesia Press, 1972; originally Le Péché originel dans La tradition patristique et théologique (Paris: Fayard, 1967)); H. M. Köster, Urstand, Fall und Erbsünde in der Scholastik (Freiburg: Herder, 1979); and, with reference to particular representatives of the tradition, J. B. Kors, O.P. La Justice primitive et le peché originel J'après S. Thomas, Bibliothèque Thomiste (Paris: Vrin, 1930); R. Martorelli Vico, 'La dottrina della giustizia originale e del peccato originale nel trattato De peccato originali di Egidio Romano', Documentie studi sulla tradizione filosofica medievale 1 (1990), 1, 227-46; P. J. Weithman, 'Augustine and Aquinas on Original Sin and the Function of Political Authority', Journal of the History of Philosophy 30 (1992), 3, 353-76. Otherwise, N. P. Williams, The Idea of the Fall and Original Sin (London: Longmans, 1927); E. Yarnold, The Theology of Original Sin (Notre Dame, Ind.: Fides Publishers, 1971); M. Flick, Il peccato originale (Brescia: Queriniana, 1972).
\end{abstract}


di proceder per tutte le sue vie,

a rilevarvi suso, fu contenta.

Né tra l'ultima notte e 'l primo die

sì alto o sì magnifico processo,

o per l'una o per l'altra, fu o fie:

ché più largo fu Dio a dar sé stesso

per far l'uom sufficiente a rilevarsi,

che s'elli avesse sol da sé dimesso;

e tutti li altri modi erano scarsi

a la giustizia, se 'l Figliuol di Dio

non fosse umilïato ad incarnarsi. ${ }^{60}$

On the other hand we have the predicament of the one who, knowing himself as called to be in, through and for God as the beginning and end of all being, knows himself also by way of the alternative project and of the drastic phenomenology of this, of the disorientation, the directionlessness, the fear, the self-inexplicability, and, as the boundary and underlying condition of these and of every other symptom of being in its farwandering, the despair contingent on radical lostness and fashioning from it a scourge of the spirit. This, then, is where Dante begins. Setting aside every preoccupation with the propaedeutics of faith and the methodology of sacred science, he begins with the substance and psychology of being in its proximity to non-being, with self itself under the aspect of imminent dissolution:

Nel mezzo del cammin di nostra vita mi ritrovai per una selva oscura, ché la diritta via era smarrita.

Ahi quanto a dir qual era è cosa dura esta selva selvaggia e aspra e forte che nel pensier rinova la paura!

Tant' è amara che poco è più morte; ma per trattar del ben ch'i' vi trovai, dirò de l'altre cose ch'i' v'ho scorte.

Io non so ben ridir com' i' v'intrai, tant' era pien di sonno a quel punto

${ }^{60}$ But because the deed is so much the more prized by the doer, the more it displays of the goodness of the heart whence it issued, the divine goodness which puts its imprint on the world, was pleased to proceed by all its ways to raise you up again; nor between the last night and the first day has there been or will there be so exalted and so magnificent a procedure, either by the one or by the other; for God was more bounteous in giving himself to make man sufficient to uplift himself again, than if he solely of himself had remitted; and all other modes were scanty in respect to justice, if the Son of God had not humbled himself to become incarnate. 
che la verace via abbandonai ...

Questi parea che contra me venisse con la test'alta e con rabbiosa fame, sì che parea che l'aere ne tremesse.

Ed una lupa, che di tutte brame sembiava carca ne la sua magrezza, e molte genti fé già viver grame,

questa mi porse tanto di gravezza con la paura ch'uscia di sua vista, ch'io perdei la speranza de l'altezza.

(Inf. I.1-12 and 46-54) ${ }^{61}$

With this, then, the way is open for a discourse turning, certainly, upon an act of intellection, of theological right understanding but, more fundamentally still, on intellection as a means of actualization $e x$ parte subiecti, as that whereby self emerges into the fullness of its now transfigured humanity. First, then, comes the moment of self-encounter, the moment in which, quickened by grace as a principle of encouragement, the soul more than ever anxious in respect of the integrity and of the intelligibility of its presence in the world looks into the face, not of love, but of lovelessness as the truth of its own being and of being generally in the world, a process issuing, in the recesses of the pit, in a sense of the nothingless of it all, of being under the aspect of non-being. But in so far as lovelessness presupposes love as the ground of its intelligibility, the way is open to renewal, the moment of self-encounter thus giving way to that of self-reconfiguration, to the moment in which, with the taking of the guilt of estrangement into itself as the condition of its liquidation, the soul sets about bringing home every otherwise random love-impulse of the spirit to the kind of love given with the act itself of existence - a process culminating, Dante thinks, in a state of perfect spiritual selfpossession, of governance as a matter of self-governance (the 'per ch' io te sovra te corono e mitrio' of Purg. XXVII.142). ${ }^{62}$ But that, resplendent as it is, is not all, for the kind of self-encounter and self-reconfiguration whereby

${ }^{61}$ Midway in the journey of our life I found myself in a dark wood, for the straight way was lost. Ah, how hard it is to tell what that wood was, wild, rugged, harsh; the very thought of it renews my fear! It is so bitter that death is hardly more so. But, to treat of the good that I found in it, I will tell of the other things I saw there. I cannot rightly say how I entered it, I was so full of sleep at the moment I left the true way ... [the lion] seemed to be coming at me, head high and raging with hunger, so that the air seemed to tremble at it; and a she-wolf, that in her leanness seemed laden with every craving and had already caused many to live in sorrow; she put such heaviness on me with the fear that came from the sight of her that I lost hope of the height.

${ }^{62}$ wherefore I crown and mitre you over yourself. 
the soul knows itself in the possibility of new life is in turn taken up in the kind of self-transcendence whereby it knows itself in the now ecstatic substance of self, in the opening out of self upon the kind of deiformity to which it is called from beforehand as to its proper destiny. ${ }^{63}$ Having, in other words, known and struggled with self in its endless capacity for self-destruction, the soul at last rejoices in the kind of transhumanity (the 'trasumanar' of Par. I.70-72) proper to it as the most immanent of its immanent possibilities. Such at any rate is the Christian hope as Dante sees and understands it, at which point we return at last to Dante and Aquinas; for if on the one hand Thomas remains the undisputed master of Christian-theological discourse on the plane of the horizontal, of the forward thrust of the mind as it attends to the business of precise intellection, then Dante remains the undisputed master of Christiantheological discourse on the plane of the vertical, of the downward thrust of the mind - which is also its upward thrust - as it attends to the business of disclosure, of laying open the deep substance of self as embarked on the way of death and resurrection.

5. Where, then, does this leave us with respect to the massive and at times militant intervention of Nardi, Gilson and Foster with which we began? It leaves us first with an enhanced appreciation of what between them they accomplished in this area of Dante scholarship, for it is thanks to their combination of courage and clearsightedness that, not so much Dante, as we ourselves are set free for a new order of enquiry, for an account of the precise nature ( $a$ ) of Dante's reading and reception of the Thomist text, and $(b)$ of the theological issue as he himself sees and understands it. Of the second of these things, we have said sufficient, Dante's being a proposal of the theological project by way, not so much of the content in and for itself of dogmatic consciousness, as of the situation into which that content enters as a co-efficient of new life, as that whereby, in and through an ever more refined sense of its own

\footnotetext{
${ }^{63}$ For the terminology ('trasumanar'), S. Botterill, Dante and the Mystical Tradition: Bernard of Clairvaux in the Commedia (Cambridge: Cambridge University Press, 1994), Chapter 6 ('From deificari to transumanar? Dante's Paradiso and Bernard's De diligendo Deo'), pp. 194-241; V. Capelli, 'Lettura del canto I del Paradiso. L'esperienza del "trasumanar", in Letture dantesche tenute nella pieve di Polenta e nella basilica di S. Mercuriale in Forli (19962005) (Genoa and Milan: Marietti, 2006), pp. 215-29; G. Jori, 'Per un commento di "trasumanar e organizzar" (appunti di lettura)', in E'n guisa d'eco i detti e le parole. Studi in onore di Giorgio Barberi Squarotti, 3 vols (Alessandria: Edizioni dell'Orso, 2006), vol. 2, pp. 959-81; B. Guthmüller, “"Trasumanar significar per verba / non si poria”. Sul I canto del Paradiso', L'Alighieri. Rassegna Jantesca, n.s. 29 (2007), 48, 107-20 (from the German original in the Deutsches Dante-Jahrbuch 82 (2007), 67-85, and updated in Mito e metamorfosi. Da Dante al Rinascimento (Rome: Carocci, 2009), pp. 75-90).
} 
innermost reasons, the soul at last comes home to itself in the fullness of its proper humanity, its proper humanity being nothing other than its proper transhumanity. As far, however, as the first of them is concerned, namely the kind of relationship subsisting between the reader and the text he cherishes and by which he is in turn cherished, it is a question of the way in which otherness in respect of the idea pure and simple points on beyond itself to the kind of sameness whereby it is authorized from out of the depths. Something of the kind, at any rate, is the object of Dante's meditation in the exquisite tenth canto of the Paradiso, where, given the power of the idea, not so much to unite, as to divide one man from another, each alike remains indispensable to the collective proclamation:

Tu vuo' saper di quai piante s'infiora questa ghirlanda che 'ntorno vagheggia la bella donna ch'al ciel t'avvalora.

Io fui de li agni de la santa greggia che Domenico mena per cammino u' ben s'impingua se non si vaneggia.

Questi che m'è a destra più vicino, frate e maestro fummi, ed esso Alberto è di Cologna, e io Thomas d'Aquino.

Se sì di tutti li altri esser vuo' certo, di retro al mio parlar ten vien col viso girando su per lo beato serto.

Quell' altro fiammeggiare esce del riso di Grazïan, che l'uno e l'altro foro aiutò sì che piace in paradiso.

Laltro ch'appresso addorna il nostro coro, quel Pietro fu che con la poverella offerse a Santa Chiesa suo tesoro.

La quinta luce, ch'è tra noi più bella, spira di tale amor, che tutto 'l mondo là giù ne gola di saper novella: entro v'è l'alta mente u' sì profondo saver fu messo, che, se 'l vero è vero, a veder tanto non surse il secondo.

Appresso vedi il lume di quel cero che giù in carne più a dentro vide l'angelica natura e 'l ministero.

Ne l'altra piccioletta luce ride quello avvocato de' tempi cristiani del cui latino Augustin si provide. 
Or se tu l'occhio de la mente trani

di luce in luce dietro a le mie lode, già de l'ottava con sete rimani.

Per vedere ogne ben dentro vi gode

l'anima santa che 'I mondo fallace

fa manifesto a chi di lei ben ode.

Lo corpo ond' ella fu cacciata giace

giuso in Cieldauro; ed essa da martiro

e da essilio venne a questa pace.

Vedi oltre fiammeggiar l'ardente spiro

d'Isidoro, di Beda e di Riccardo, che a considerar fu più che viro.

Questi onde a me ritorna il tuo riguardo, è 'l lume d'uno spirto che 'n pensieri gravi a morir li parve venir tardo:

essa è la luce etterna di Sigieri, che, leggendo nel Vico de li Strami, silogizzò invidïosi veri.

(Par. X.91-138) ${ }^{64}$

In a passage decisive for the now sublime sociology of it all, overagainstness gives way to alongsidedness as a paradigm of consciousness, to a species of circuminsession or 'inseatedness' as a means of seeing and

${ }^{64}$ You wish to know what plants these are that enflower this garland, which amorously circles round the fair lady who strengthens you for heaven. I was of the lambs of the holy flock which Dominic leads on the path where there is good fattening if they do not stray. He that is next beside me on the right was my brother and my master, and he is Albert of Cologne, and I Thomas of Aquino. If thus of all the rest you would be informed, come, following my speech with your sight, going round the blessed wreath. The next flaming comes from the smile of Gratian who served the one and the other court so well that it pleases in paradise. The other who next adorns our choir was that Peter who, like the poor widow, offered his treasure to holy Church. The fifth light, which is the most beautiful among us, breathes with such love that all the world there below thirsts to know tidings of it. Within it is the lofty mind to which was given wisdom so deep that, if the truth be true, there never rose a second of such full vision. At its side behold the light of that candle which, below in the flesh, saw deepest into the angelic nature and its ministry. In the next little light shines that defender of the Christian times, of whose discourse Augustine made use. If now you are bringing your mind's eye from light to light after my praises, you are already thirsting for the eighth. Therewithin, through seeing every good, the sainted soul rejoices who makes the fallacious world manifest to any who listen well to him. The body from which it was driven lies down below in Cieldauro, and he came from martyrdom and exile to this peace. See, flaming beyond, the glowing breath of Isidore, of Bede, and of Richard who in contemplation was more than man. This one from whom your look returns to me is the light of a spirit to whom, in his grave thoughts, it seemed that death came slow. It is the eternal light of Siger who, lecturingin Straw Street, demonstrated invidious truths. 
celebrating the relationship between one man and another in the moment of emergence, this in turn pointing on to the nature of Dante's relationship with those of his auctores he most cherished - to a relationship lit up and sustained by its own perichoretic intensity. ${ }^{65}$

${ }^{65} \mathrm{O}$ light eternal, who alone abidest in thyself, [and, known to thyself and knowing, lovest and smilest on thyself!]. A. Deneffe, 'Perichoresis, circumincessio, circuminsessio,' in Zeitschrift für katbolische Theologie 47 (1923), 497-532; D. F. Stramara Jr, 'Gregory of Nyssa's Terminology for Trinitarian Perichoresis', Vigiliae Christianae 52 (1998), 3, 25763; R. Cross, 'Perichoresis, Deification, and Christological Predication in John of Damascus', Medieval Studies 62 (2000) , 69-124, after Gregory Nazianzen, Epistula ci.6; xxii.4; John of Damascus De fide ortho. i.14, etc. 